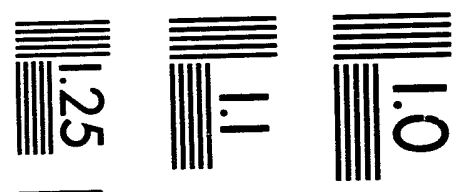

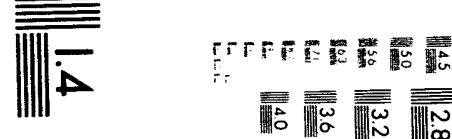

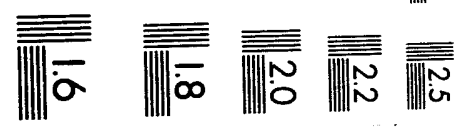



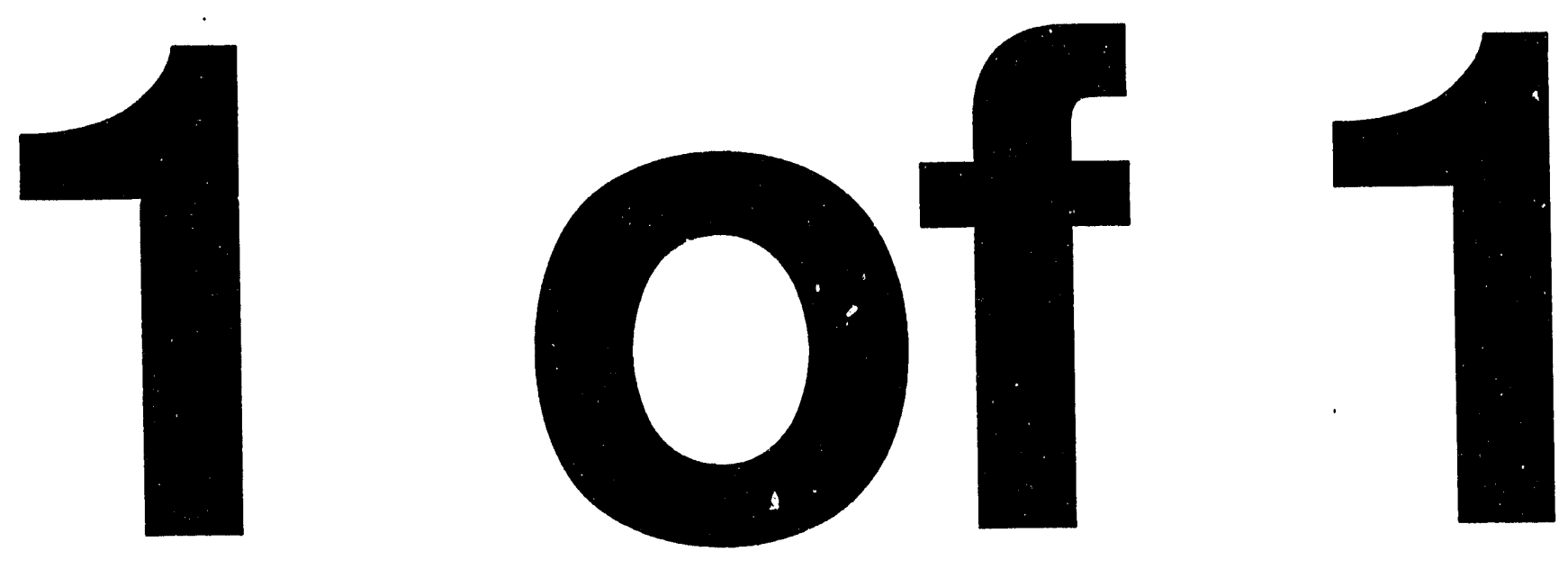
Issued: December 1993

Preliminary Conceptual Model

for Mineral Evolution in Yucca Mountain

C. J. Duffy 


\title{
PRELIMINARY CONCEPTUAL MODEL \\ FOR \\ MINERAL EVOLUTION IN YUCCA MOUNTAIN
}

by

C. J. Duffy

\begin{abstract}
I present a model for mineral alteration in Yucca Mountain, Nevada, that suggests that the mineral transformations observed there are primarily controlled by the activity of aqueous silica. The rate of these reactions is related to the rate of evolution of the metastable silica polymorphs opal-CT and cristobalite assuming that $a_{\mathrm{SiO}_{2(\mathrm{aq})}}$ is fixed at the equilibrium solubility of the most soluble silica polymorph present. The rate equations accurately predict the present depths of disappearance of opal-CT and cristobalite. The rate equations have also been used to predict the extent of future mineral alteration that may result from emplacement of a high-level nuclear waste repository in Yucca Mountain. Relatively small changes in mineralogy are predicted, but I base these predictions on the assumption that emplacement of a repository would not increase the $\mathrm{pH}$ of water in Yucca Mountain nor increase its carbonate content. Such changes may significantly increase mineral alteration.
\end{abstract}

Some of the reactions currently occurring in Yucca Moun'ain cosisume $\mathrm{H}^{+}$and $\mathrm{CO}_{3}^{2-}$. Combining reaction rate models for these reintions with water chemistry data may make it possible to estimate water flox through the basal vitrophyre of the Topopah Spring Member and to lielis a com tive direction and rate of flow of groundwater in Yucca Mountait:

\section{INTRODUCTION}

Potential detrimental effects of glass and mineral alteration may affect the suitability of Yucca Mountain in south central Nevada as a potential site for an underground highlevel radioactive waste repository. This report, sponsored by the Nevada Nuclear Waste Storage Investigations (NNWSI) Project of the U.S. Department of Energy, presents a 
preliminary conceptual model for mineral alteration in Yucca Mountain. I present a preliminary assessment of mineral alteration that may occur in Yucca Mountain over the lifetine of a repository. Mineral alteration will occur in Yucca Mountain because at least some of the current mineral assemblages are metastable. I am primarily concerned with the rate of transformation of these metastable mineral assemblages. The validity of performance assessment based on current rock properties is directly correlated to the persistence of current mineral assemblages. If transformation of the current mineral assemblages is unlikely over the lifetime of the repository, we can use current rock properties with confidence in performance assessment. However, possible mineral alteration could affect repository performance by changing the sorptive properties of the rock, by changing rock mechanical properties (such as strength), by changing hydraulic properties (such as permeability and porosity), or by producing or consuming water.

Mineral transformations occur in Yucca Mountain for two possible reasons. First, much of the present mineralogy is metastable because many of the minerals were formed from the low-temperature alteration of glass. The silica phases opal-CT, tridymite, and rristobalite are metastable with respect to quartz under the conditions present in Yucea Mountain. Field observations suggest that clinoptilolite and mordenite are also metastable. Because of this metastability, mineral transformations will take place in Yucca Mountain even if a repository is not built there. Second, the heating caused by a repository may induce or accelerate mineral transformations. These transformations may be caused by different mineral assemblages becoming stable or by the increased rate of transformation of metastable assemblages cansed by heating. The dominant minerals in Yucca Mountain are the silica polymorphs (triclymite, opal-CT, cristobalite, and quartz), clinoptilolite, mordenite, clays, analcime, and allali-feldspars. Lesser amounts of kaolinite and calcite are present and involved in reactions among the major phases.

The effects of heat and time are major factors that determine the present mineral distribution. The validity of the conceptual model produced by this task can therefore be at least partially assessed by how well it explains the present mineral distribution. I hypothesize that the mineral transformations in Yucea Mountain are largely controlled by the decreasing acpueous silica activity caused by the evolution of the metastable silica polymorphs to quartz. The transition of analeime plus $\mathrm{SiO}_{2}$ to albite is the only major mineral reaction observed in Vucca Mountain that cannot plausibly be attributed to clecreasing aqueous silica activity. This transformation is probably dependent on the kineties of aluminum/silieon orelering in albite, but may also reguire a higher temperature 
than shose currently existing in Yucca Mountain. Transformation of the metastable silica polymorphs and its effects on the transformation of clays and zeolites will be my primary emphasis. I will also emphasize the rates of evolution of the metastable silica polymorphs, their relationship to the aqueous silica activity, and their effect on reactions among other minerals.

\section{MINERALOGY}

The mineralogy of Yucca Mountain, described in many reports on individual drill holes, is summarized by Bish and Vaniman (1985). More recent mineral abundance data have been obtained for drill holes J-13, UE-25a\#1, and USW G-1 (Bish and Chipera, 1986). Electron microprobe mineral compositional data also appear in many of the individual reports. Electron microprobe data for clinoptilolite, analcime, and authigenic alkali feldspar have been collected by Broxton et al. (1986). Electron microprobe compositional analyses of mordenite are detailed by Caporuscio et al. (1982) and by Carlos (1985, 1987). Clay analyses are cletailed in Caporuscio et al. (1982), Vaniman et al. (1984), and Levy (1984). The major minerals in Yucca Mountain fall into the categories of zeolites, clays, alkali feldspars, silica polymorphs, and calcite. The zeolites are primarily clinoptilolite, mordenite, and analcime. The clays are principally smectites, interlayered smectite/illite, and illite with lesser kaolinite. Tridymite, opal-CT, cristobalite, and quartz make up the silica polymorphs. Additional phases such as chlorite, laumontite, and iron, iron tita nium, and manganese oxides and hydroxides are present in low abundance or very linited distribution. Biotite and hornblende are also present in limited abundance as phenocrysts.

The compositions of the major phases are variable. In order to model the chemical reactions among these phases, representative compositions have been chosen based on available microprobe analyses or accepted mineral compositions. These compositions are given in Table I. Clinoptilolite generally has $\mathrm{Si} / \mathrm{Al}$ (atom ratio) between 4 and 5 (Broxton et al., 1987). The $\mathrm{Si} / \mathrm{Al}$ ratios for a small group of calcium-rich clinoptilolites are between 2.8 and 3.6. The relative abundances of sodium, potassium, and calcium in Yucca Mountain clinoptilolites are highly variable. Few analyses are available for mordenite due to its generally fine grained nature and tendency to be intergrown with other minerals. However, $\mathrm{Si} / \mathrm{Al}$ tends to be somewhat higher in mordenite than in clinoptilolite, generally between 5 and 6 . The mordenite also appears to be enriched in sodium and depleted in potassium relative to nearby clinoptilolite. Calcium may also be somewhat depleted relative to sodium, but probably less so than potassium. Analcime is essentially a pure sodium mineral with only very minor amounts of potassium or calcium. The Si/Al ratio 
of the Yucca. Mountain analcimes range from 2.3 to 2.9 and show a bimodal distribution centered about approximately 2.53 and 2.75 .

\section{TABLE I}

\section{REPRESENTATIVE MINERAL COMPOSITIONS FOR YUCCA MOUNTAIN}

$\begin{array}{ll}\text { Clinoptilolite } & =\left(\frac{1}{2} \mathrm{Ca}, \mathrm{Na}, \mathrm{K}\right)_{2.18} \mathrm{Al}_{2.18} \mathrm{Si}_{9.82} \mathrm{O}{ }_{24} \cdot \mathrm{nH}_{2} \mathrm{O} \\ \text { Mordenite } & =\left(\frac{1}{2} \mathrm{Ca}, \mathrm{Na}, \mathrm{K}\right)_{1.8} \mathrm{Al}_{1.8} \mathrm{Si}_{10.2} \mathrm{O}_{24} \cdot \mathrm{nH}_{2} \mathrm{O} \\ \text { Analcime } & =\mathrm{Na} .86 \mathrm{Al}_{.86} \mathrm{Si}_{2.14} \mathrm{O}_{6} \cdot \mathrm{nH}_{2} \mathrm{O} \\ \text { Sinectite } & \left.=\left(\frac{1}{2} \mathrm{Ca}, \mathrm{Na}\right)_{1.1}(\mathrm{Mg}, \mathrm{Fe})_{.9} \mathrm{Al}_{3.3} \mathrm{Si}_{7.8} \mathrm{O}_{20}(\mathrm{OH})_{4} \cdot \mathrm{nH}_{2} \mathrm{O}\right) \\ \text { Illite } & =\mathrm{K}_{1.9}(\mathrm{Mg}, \mathrm{Fe})_{.9} \mathrm{Al}_{4.1} \mathrm{Si}_{7} \mathrm{O}_{20}(\mathrm{OH})_{4} \\ \text { Traolinite } & =\mathrm{Al}_{4} \mathrm{Si}_{4} \mathrm{O}_{10}(\mathrm{OH})_{8} \\ \text { K-feldspar } & =\mathrm{KAlSi}_{3} \mathrm{O}_{8} \\ \text { Albite } & =\mathrm{NaAlSi}_{3} \mathrm{O}_{8} \\ \text { Calcite } & =\mathrm{CaCO}_{3}\end{array}$

The clays in Yucea Monntain are smectites. interlayered smectite/illite, and illites with small amounts of kaolinite. The smectites contain sodium, calcium, and potassium in the interlayer sites. The $\mathrm{Al} /(\mathrm{Mg}+\mathrm{Fe})$ atom ratio varies slightly but is about 3.7. A small amount of aluminum is present in the tetrahedral sites. The illites are potassium rich with only minor calcium and sodium. The amount of iron and magnesium in the octahedral sites is about the same as in the smectite. The aluminum content of the tetrahedral sites is higher than in the smectites. The $\mathrm{Mg} / \mathrm{Fo}$ ration in both the illites and snnectites is variable and appears to reflect the bulk composition of the rock. Compositional data are not available for the kasolinite from Yucea Monntain. Kaolinite has linited compositional variability (Deer et al., 1962); the irleal formula has been used.

The silica polymorphs are all essentially $\mathrm{SiO}_{2}$. Water is generally present in the opal as are aluminum, sodium, and potassium, but they are present in minor amounts. The authigenic alkali feldspars are nearly pure albite and orthochase cuelmembers, although the authigenic K-feldspars show a small amonet of silicon substitution for aluminum in the ideal formula (Broxton ot al., 1987). Intermediate sanidine and plagioclase plenocrysts are present as well as considerable intermediate alkali foldspar (Broxton et al., 1982) that is the product of elevated temperature devitrification during initial cooling of the tuff. Calcite analyses ane not avalable. lut this phase is probably nomly pure (aC() 3 with possible minor magnosium. 


\section{CONTROLS ON MINERAL ALTERATION}

The mineralogic investigations of Yucca Mountain cited earlier reveal a consistent variation in mineralogy with depth. Unaltered glass is common in the upper part of the mountain. It is replaced by clinoptilolite and mordenite with increasing depth followed by analcime and finally albite. Smyth (1982) related these transformations to increasing temperature and suggested that in the presence of dilute waters the transition from clinoptilolite to analcime should take place at 90 to $100^{\circ} \mathrm{C}$. However, data presented by Honda and Muffler (1970) and Keith et al. (1978) for drill holes in Yellowstone National Park show alternating zones of clinoptilolite and analcime in crill holes over the temperature interval from 50 to $150^{\circ} \mathrm{C}$. Dibble and Tiller (1981) present an alternate model for the evolution of tuffaceous sediments in which clinoptilolite and smectite are assumed to be metastable phases that crystallize from supersaturated solutions resulting from glass dissolution. Acrording to Dibble and Tiller (1981), a more ordered assemblage of feldspar, illite, and perhaps analcine is more stable, but is not observed initially because the more disordered smertites and zeolites crystallize more rapidly. The model of Dibble and Tiller (1981) tends to agree with the observed interlayering of clinoptilolite and analcime, but it suggests that mixtures of (linop ilolite with analcime and authigenic feldspar should be common. However, the transition zones between clinoptilolite and analcime bearing rocks are albrupt and the minerals coexist over a limited stratigraphic isterval.

Lerrisk (1983) estinated thermodynamic clata for clinoptilolite and mordenite and used these data in performing reaction-path calculations of groundwater chemistry and mineral formation. Kerrisk (1983) found that if quarty was allowed to precipitate, clinoptilolite and mordenite did not appear in the final mineral assemblage in any of his calculations from 25 to $175^{\circ} \mathrm{C}$. However, if quartz and chalcedony precipitation was suppressed so that the acueous silica activity could not fall below cristobalite saturation, clinoptilolite and mordenite appeared in the final assemblage at all temperatures. This is in agreement with the general conclusions of Dibble and Tiller, because only the assemblage which contains cuartz can be the stable assemblage. However, it also points out that a distinction must be made between the stability of individual mineral phases and the overall assemblage.

Kerrisk's (1983) results can be better understood by observing that the general reaction of clinoptilolite to analcine is 


$$
\mathrm{Na} \text { - clinoptilolite } \rightarrow \text { Analcime }+\mathrm{m} \cdot \mathrm{SiO}_{2}+\mathrm{n} \cdot \mathrm{H}_{2} \mathrm{O} \text {. }
$$

Similar reactions can be written for reaction of the potassium and calcium components of clinoptilolite to K-feldspar and/or smectite. In all cases, the reactions involve the production of $\mathrm{SiO}_{2}$. The equilibrium constant, $\mathrm{K}$, for $\mathrm{Eq}$. (1) can be written

$$
K=\frac{a_{\text {analcime }} a_{\mathrm{SiO}_{2(\text { aq })}}^{\mathrm{m}} a_{\mathrm{H}_{2} \mathrm{O}}^{\mathrm{n}}}{a_{\mathrm{Na}-\text { clinoptilolite }}}
$$

where $a$ is the chemical activity. Because analcime is present as a pure sodium endmember, its activity is 1 as is the activity of $\mathrm{H}_{2} \mathrm{O}$ for the clilute groundwaters of Yucca Mountain. To a first approximation, the activity of Na-clinoptilolite is the mole fraction, $x$, of the sodium endmember present in the clinoptilolite. Equation (2) therefore reduces to

$$
K=\frac{a_{\mathrm{SiO}}^{\mathrm{m}} \mathrm{O}_{2(\mathrm{aq})}}{x_{\mathrm{Na}-\mathrm{clinop}} \text { tilolite }}
$$

Equation (3) demonstrates that at a given temperature and clinoptilolite composition an aqueous silica activity exists at which the clinoptilolite and analcime are in equilibrium. Above that value, clinoptilolite is stable; below that value analcime is stable. Kerrisk's (1983) calculations suggest that the equilibrium value is between cristobalite and chalcedony saturation. I wish to stress that, although the assemblage of cristobalite, or opal-CT, and clinoptilolite is probably metastable as suggested by Dibbie and Tiller (1981), if the acqueous silica activity is high, the clinoptilolite may be stable even though the total assemblage is not. If the aqueous silica artivity is high, minerals that are part of the most stable assemblage could react to form clinoptilolite.

\section{AQUEOUS SILICA ACTIVITY}

The forms of solid $\mathrm{SiO}_{2}$ are regulating factors controlling the aqueous silica. Fig. 1 shows the solubility of varions forms of $\mathrm{SiO}_{2}$ based on the analysis of Walther and Holgeson (1977), and presents water composition data from Yucca Mountain and vicinity (Kerrisk, 1987). The "beta-cristobalite" in Walther and Helgeson (1977) is almost certainly a highly disordered opal-C'T (Murata and Larson, 1975). Opal-CT has varying degrees of stacking clisorder. It varies continum nsly from highly disordered opal-C'T to well-ordered cristobalite. I therefore assume that the solubility of opal-C'T varies between that of "beta-cristobalite" 
and cristobalite. If an opal-CT is more disordered than "beta-cristobalite," the solubility" that opal-CT is probably slightly higher than "beta-cristobalite". Most of the waters fall within the range of opal-CT saturation. Some of the analyses above "beta-cristobalite" saturation may represent the effects of glass clissolution, but most are probably within the nodel and analytical uncertainties involved. Fig. 2 shows aqueous silica analyses of waters from Yucca Mountain and the immediate vicinity. All of the waters fall within the opal-C.T saturation field, with the exception of the high-temperature sample from UE-25b\#1. Most of the interval that this sample from UE-25h\#1 comes is probally at sufficient depth that quart $z$ is the only form of $\mathrm{SiO}_{2}$ present.

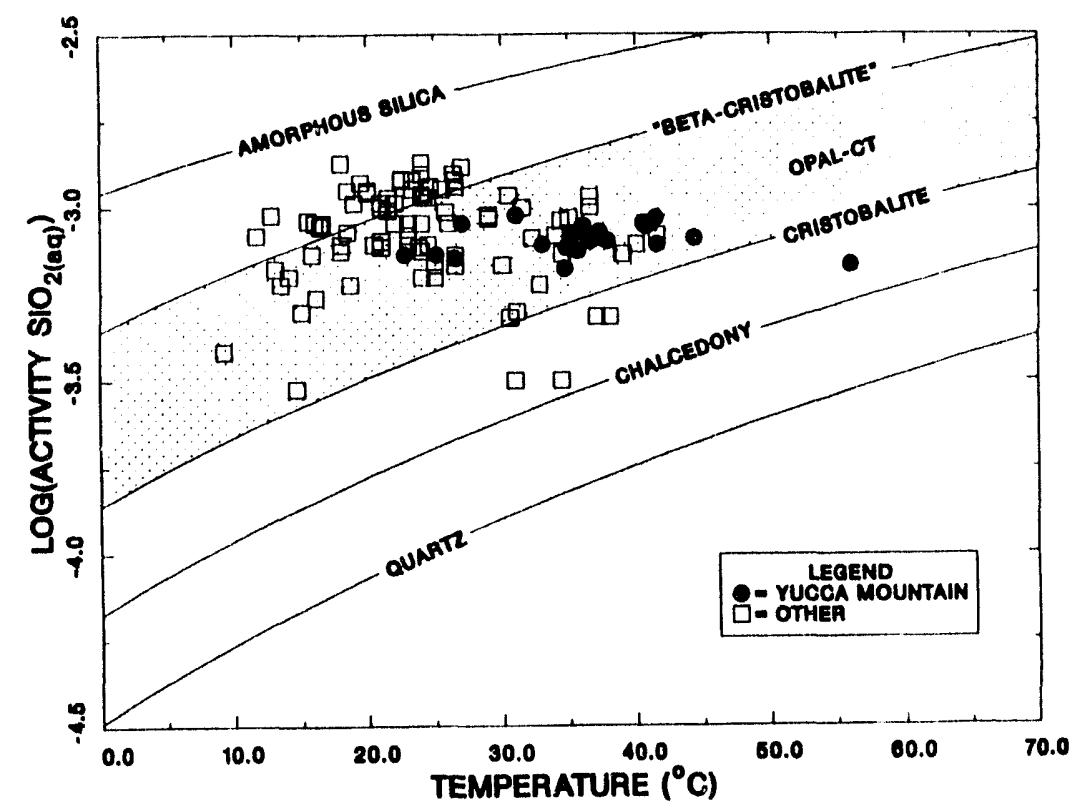

Fig. 1. Aqueous silica content of waters from Yucea Momtain and vicinity. Waters labeled "Other" are not from Yucea Mountain, but are from the general area (Kerrisk, 1987). Shaded area represents the probable range of opal-C'T solubility.

Most of the water samples were obtained by pumping the entire well so that the measured temperatures and silica concentrations are composite numbers weighted in favor of zones of high flow. Fig. 3 shows temperatures and silica concentrations from packed-off zones within wolls. Although silica solubility generally increases with increasing temperature for a given mineral, the deeper, hotter samples from these wells show consistently lower dissolved silica than do the cooler samples taken higher in the well. The more solnble silica polymorphs present at shallower depths are replaced by quartz at greater depth. 


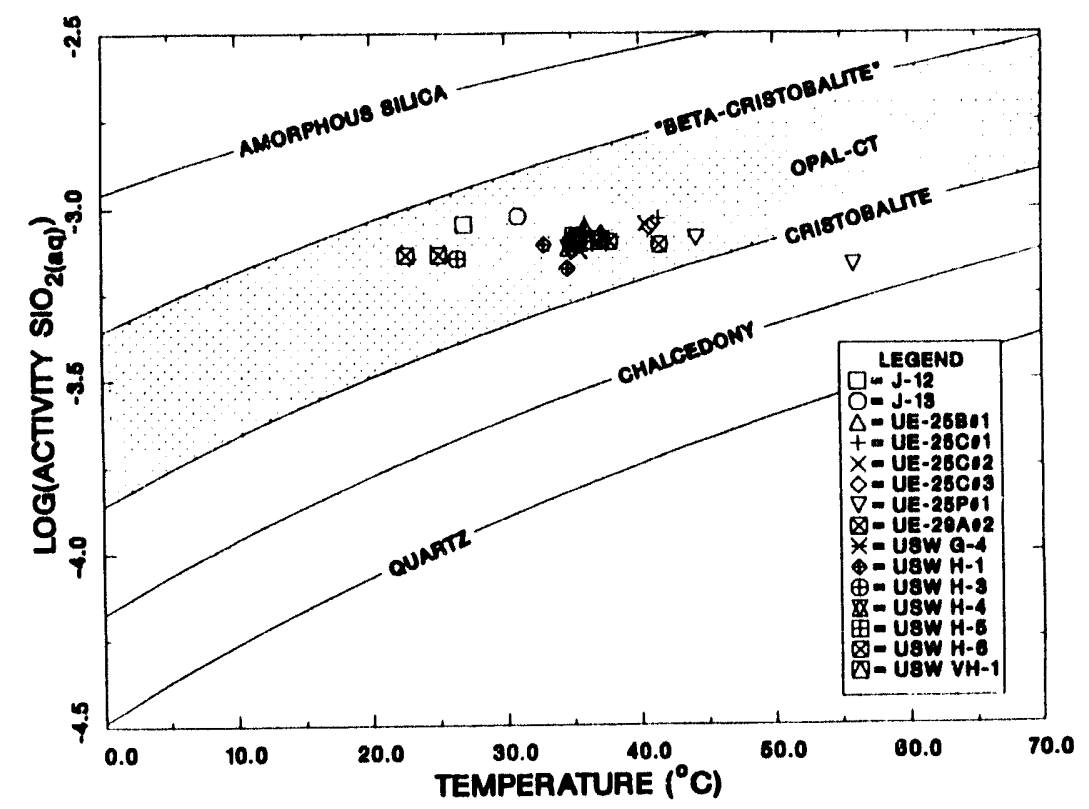

Fig. 2. Adueous silica content of waters from Yuca Mountain and immediate vicinity.

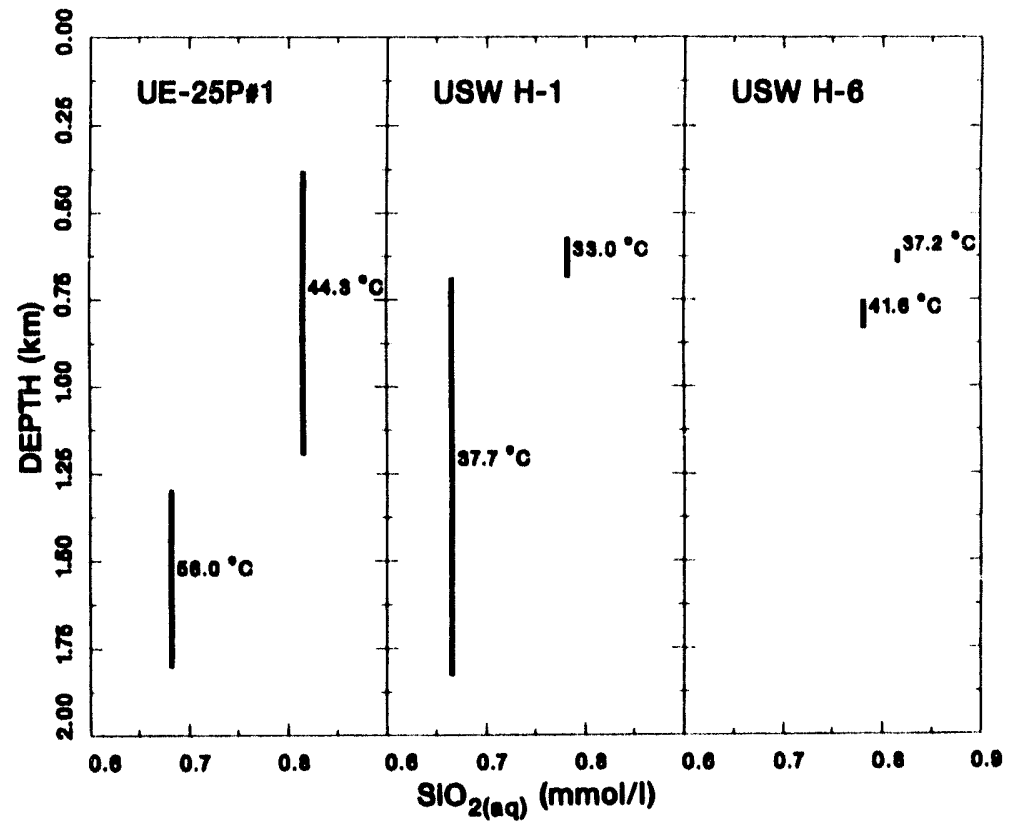

Fig. 3. Aqueous silica content and temperature of water from packed-off zones in alrill holes in Yucea Mountain. Vertical bars represent the packerd-off interval from which the water sample was taken. 
Thu'se observations suggest that the distribution of silica polymorphs controls aqueous silica activity in Yucca Mountain. Other reactions, such as the conversion of clinoptilolite to analcime, may also influence the aqueous silica activity, but this influence will be confined to the range of silica activity where the reaction is taking place.

I assume that the aqueous silica activity is controlled at the solubility of the most soluble silica polymorph present (Duffy, 1993). The high degree of correlation between the occurrence of clinoptilolite and presence of quartz and/or opal-CT or cristobalite (Honda and Muffler, 1970; Moiola, 1970; Keith et al., 1978; Bish and Chipera, 1986) can be explained by stabilization of the clinoptilolite by the high aqueous silica activity produced by the metastable silica phases. Lower aqueous silica activity produced by equilibration with quartz accounts for the appearance of analcime with quartz only.

\section{MINERAL ALTERATION IN YUCCA MOUNTAIN}

The transformation of clinoptilolite must produce phases in addition to analcime because only the sodium component of the clinoptilolite can be incorporated into the analcine. These additional reactions will be of the form

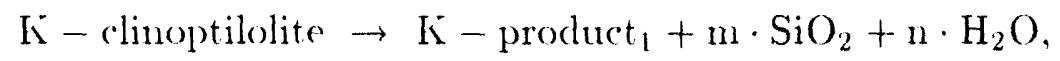

$$
\begin{aligned}
& \mathrm{Na} \text { - clinoptilolite } \rightarrow \mathrm{Na}-\text { product }_{2}+\mathrm{m} \cdot \mathrm{SiO}_{2}+11 \cdot \mathrm{H}_{2} \mathrm{O} \text {, }
\end{aligned}
$$

and

$$
\mathrm{Ca} \text { - clinoptilolite } \rightarrow \mathrm{Ca}-\text { product }_{3}+\mathrm{m} \cdot \mathrm{SiO}_{2}+\mathrm{n} \cdot \mathrm{H}_{2} \mathrm{O}
$$

I will assume, for the moment, that these reactions produce positive amounts of silica. Thus decreasing aqueous silica activity will lead to a decrease in the clinoptilolite and only one product will be produced in addition to $\mathrm{SiO}_{2}$ and $\mathrm{H}_{2} \mathrm{O}$. The equilibrium constants for Eqs. (4), (5), and (6) are

$$
\Lambda=\frac{a_{S i O_{2(a q)}}^{m} x_{K} \text {-product }}{r_{S-c l i n o p t i l o l i t e}}
$$




$$
\begin{aligned}
& K=\frac{a_{\mathrm{SiO}_{2(\mathrm{aq})}}^{\mathrm{m}} x_{\mathrm{Na}-\text { product }_{2}}}{x_{\mathrm{Na} \text {-clinoptilolite }}} \\
& K=\frac{a_{\mathrm{SiO}_{2(\mathrm{a} q)}}^{\mathrm{m}} x_{\mathrm{Ca}-\text { product }_{3}}}{x_{\mathrm{Ca}-\text { clinoptilolite }}}
\end{aligned}
$$

respectively, where $\mathrm{K}$ - product $_{1}, \mathrm{Na}$ - product $_{2}$, and $\mathrm{Ca}$ - product $_{3}$ are the potassium, sodium, and calcium endmembers of product $_{1}$, product ${ }_{2}$, and product $_{3}$.

For a constant $x_{\text {product }}$ the equilibrium value of $x_{\text {clinoptiolite }}$ will decrease with de-

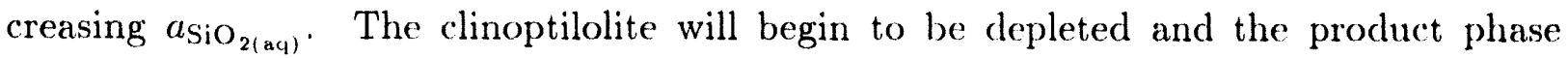
will begin to form when the equilibrium mole fraction of the endmember clinoptilolite (Na-clinoptilolite in the case of the reaction to analcime) drops below the mole fraction present in the clinoptilolite, if the product is a pure sodium, calcium, or potassium phase such as analcime. If the product phase has a variable sodium, calcium, and potassium content, as is the case with smectite, the product is stable when

$$
\sum_{i} x_{i}=1
$$

where the sum is over all components in the product. Equation (10) also applies to the sum of the mole fractions of the components of stable clinoptilolite.

The clinoptilolite's original composition depends on the minerals with which it is in equilibrium at high $a_{\mathrm{SiO}_{2(\mathrm{aq})}}$ such as mordenite, and perhaps, alkali feldspar and on the bulk composition of the rock. As $a_{\mathrm{SiO}_{2(\mathrm{aq})}}$ decreases, the $x_{1}$ for the product phase will increase (as determined by Eqs. (7), (8), and (9)), but no product will be formed until $E_{q}$. (10) is satisfied. When $E_{1}$. (10) is satisfied, the reaction of clinoptilolite to form product will progress with decreasing $a_{\mathrm{SiO}_{2(\mathrm{aq})}}$. As this reaction proceeds, the clinoptilolite will be depleted in the components with higher $x_{i}$ in the product than in the clinoptilolite and will be enriched in components with lower $x_{i}$. This reaction will continue until the sum of the $x_{i}$ for clinoptilolite falls below 1 , at which point the remainder of the clinoptilolite will react to form product.

Figs. 4-9 show the mole \% of calcium, potassium, and sodium relative to the sum of calcium, potassium, plus sodium for clinoptilolite from drill holes in Yucca Mountain (Broxton et al. 1986) as a function of depth. Figs. 4-9 also show available whole rock 
analyses. Clinoptilolite composition shows clear variations that are not associated with variations in the bulk crmposition of the rock. Figs. 10-15 show the same clinoptilolite compositional data as Figs. 4-9 plus clinoptilolite, mordenite, glass, and silica polymorph abundance data determined by x-ray diffraction. Mineral abundance data for USW G-1 and J-13 are derived from Bish and Chipera (1986), USW G-2 data are derived from Caporuscio et al. (1982), and USW G-3 and USW G-4 data are derived from Bish and Vaniman (1985). The data shown for UE-25a\#1-25b\#1h are for UE-25a\#1 from Bish and Chipera (1986) from 26.6 to $759.6 \mathrm{~m}$ and for UE-25b\#1h from Caporuscio et al. (1982) from 769.6 to $1215.5 \mathrm{~m}$. The designation UE-25a\#1-25b\#1 h is used for the combined data from these two diill holes because they are closely associated laterally, but mineralogic data are available from only a portion of each drill hole.

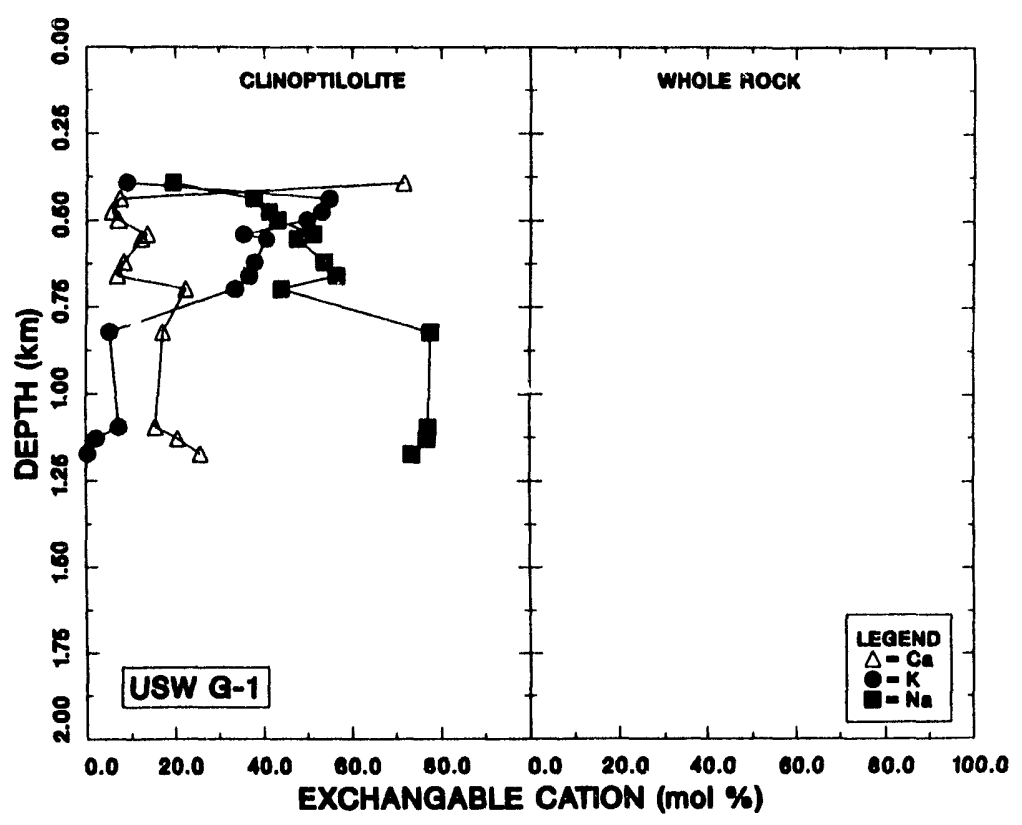

Fig. 4. Percentage of sodium, potassium, and calcium in clinoptilolite from USW G-1 relative to total sodium + potassium + calcium. No whole rock data were available for USW G-1.

Figs. 10-15 show the clear correlation between the presence of opal-CT and/or cristobalite and clinoptilolite. Clinoptilolite tends to extend to slightly greater depth than cristobalite, but in reduced abundance. Clinoptilolite, however, tends not to coexist with cristobalite and tridymite in the upper part of Yucca Mountain. Opal-CT is not shown in USW G-2, USW G-3, and USW G-4 because the distinction was not made between cristobalite and opal-CT when these analyses were made. In USW G-1, UE-25a\#1, and J-13, 


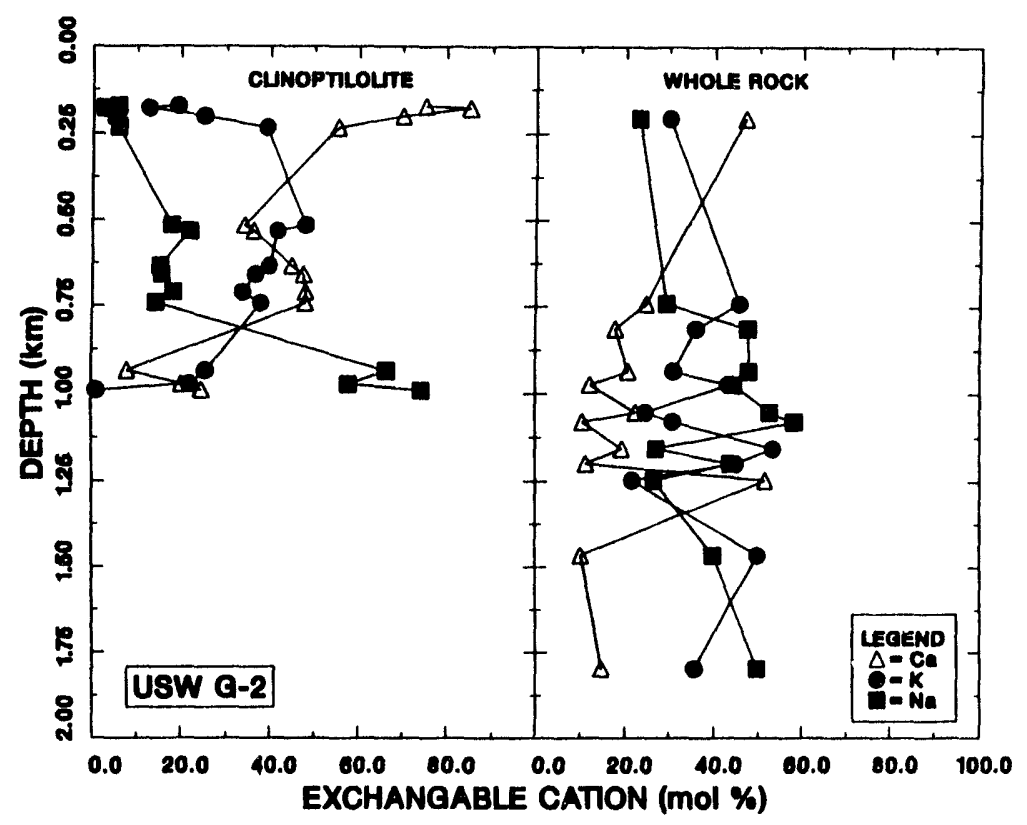

Fig. 5. Percentage of sodium, potassium, and calcium in clinoptilolite and whole rock from USW G-2 relative to total sodium + potassium + calcium.

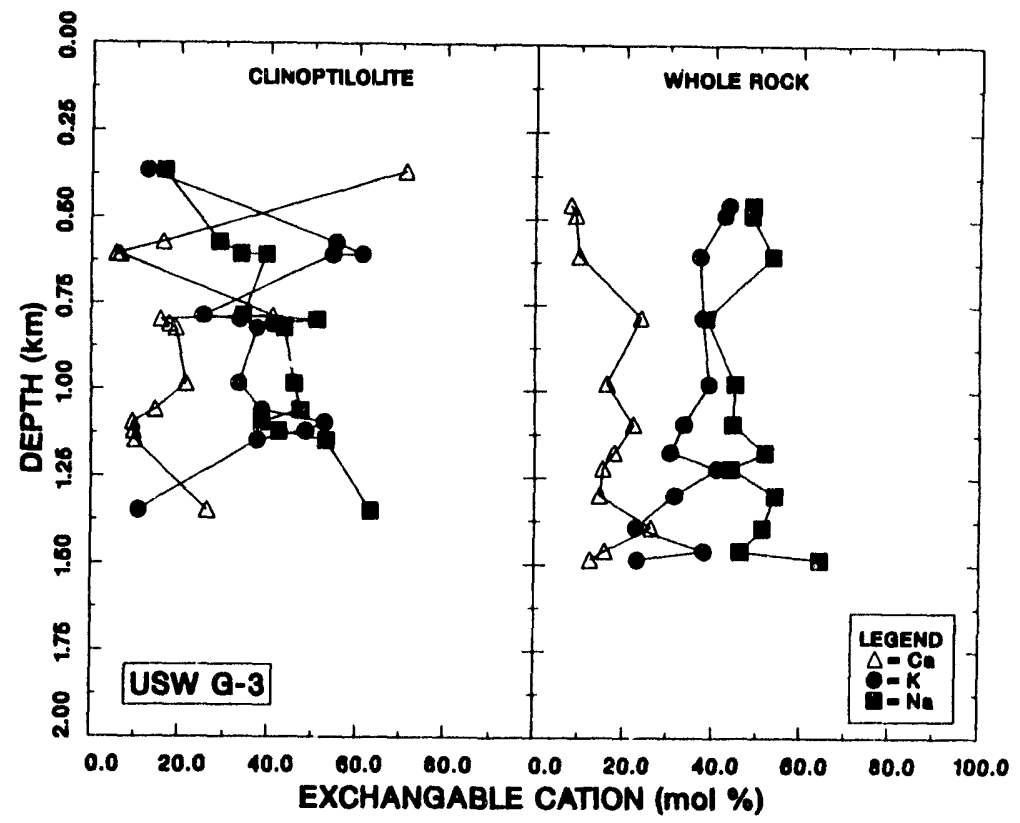

Fig. 6. Percentage of sodium, potassium, and calcium in clinoptilolite and whole rock from USW G-3 relative to total solium + potassium + calcium. 


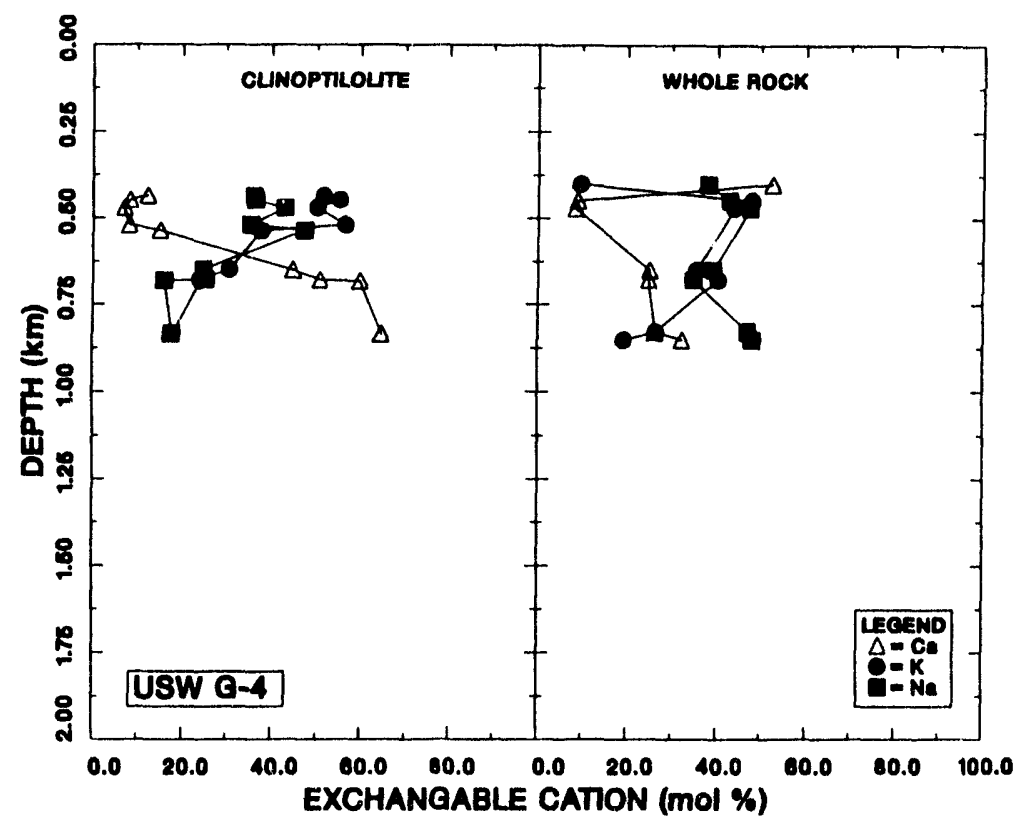

Fig. 7. Percentage of sodium, potassium, and calcium in clinoptilolite and whole rock from USW G-4 relative to total sodium + potassium + calcium.

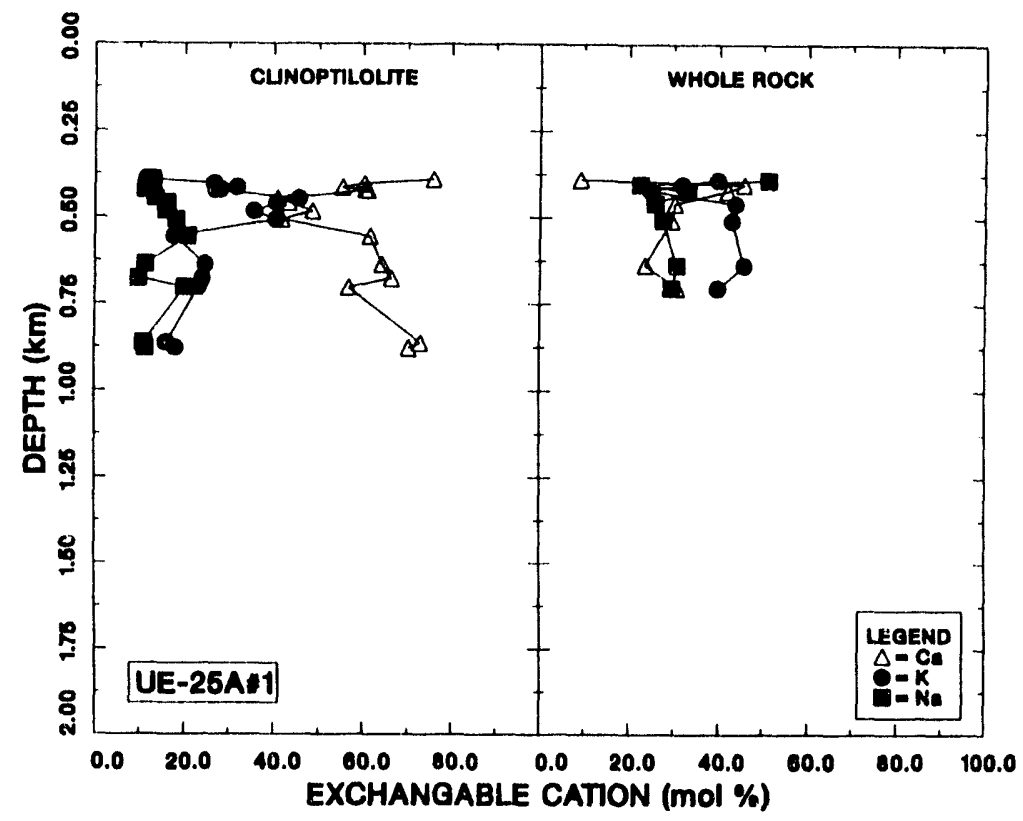

Fig. 8. Percentage of sodium, potassium, and calcium in clinoptilolite and whole rock from UE-25a\#1 relative to total sodium + potassium + calcium. 


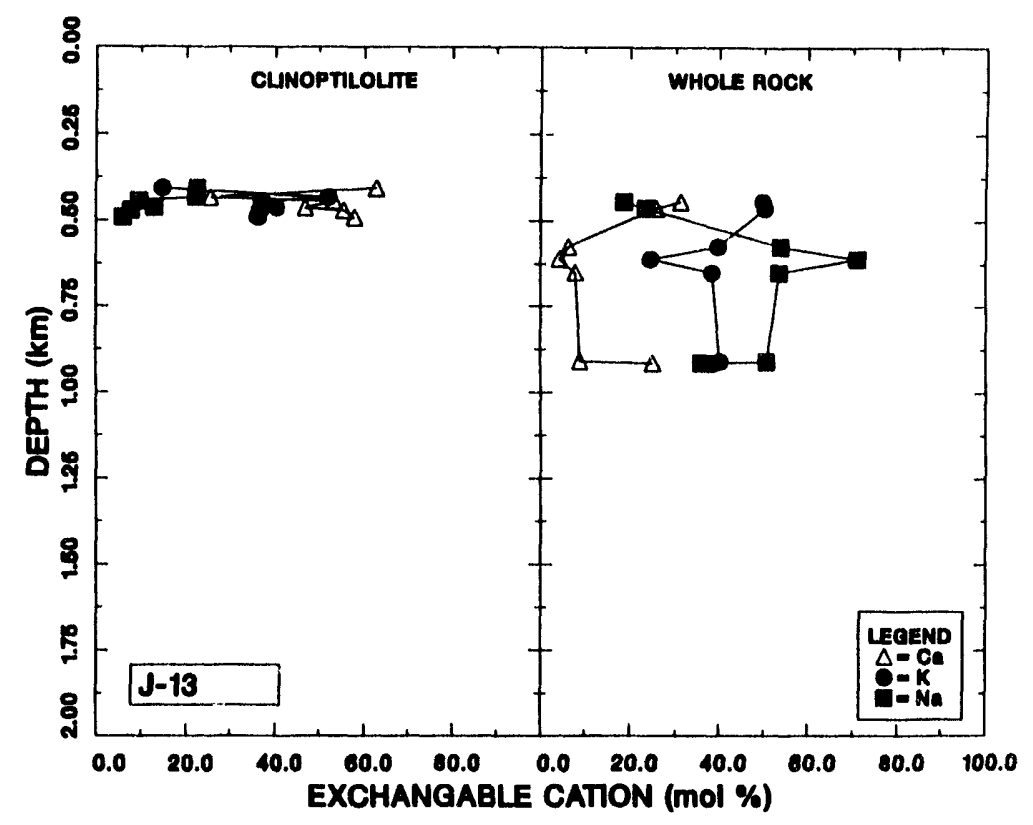

Fig. 9. Percentage of sodium, potassium, and calcium in clinoptilolite and whole rock from $\mathrm{J}-13$ relative to total sodium + potassium + calcium.

where opal-CT was distinguished from cristobalite, an excellent correlation exists between high abundance of clinoptilolite and the presence of opal-CT. Mordenite and clinoptilolite tend to occur together. The sodium-potassium-calcium contents of the clinoptilolite tend to show calcium enrichment at the top of the sequence followed at increasing depth by a zone of relatively constant composition that generally follows the bulk composition of the whole rock. At greater depth, the clinoptilolite becomes depleted in potassium.

Figs. 16-21 are compiled from the same sources as are Figs. 10-15 and show the clinoptilolite solium-potassium-calcium contents along with the mineralogic composition of the rocks. Glass, tridymite, and mica have not been included in these diagrams because they do not appear to be involved in the reactions that will be discussed. Their inclusion would only further complicate the figures. Fig. 16 of USW G-1 and Fig. 20 of UE-25a\#125b\#1h suggest that potassium depletion in the clinoptilolite is closely associated with the disappearance of opal-CT and begins before appreciable smectite crystallization. The alkali feldspar content of the rocks containing potassium-poor clinoptilolite is higher than those containing more potassium-rich clinoptilolite. Potassium depletion of the clinoptilolite is, therefore, probably due to the reaction 


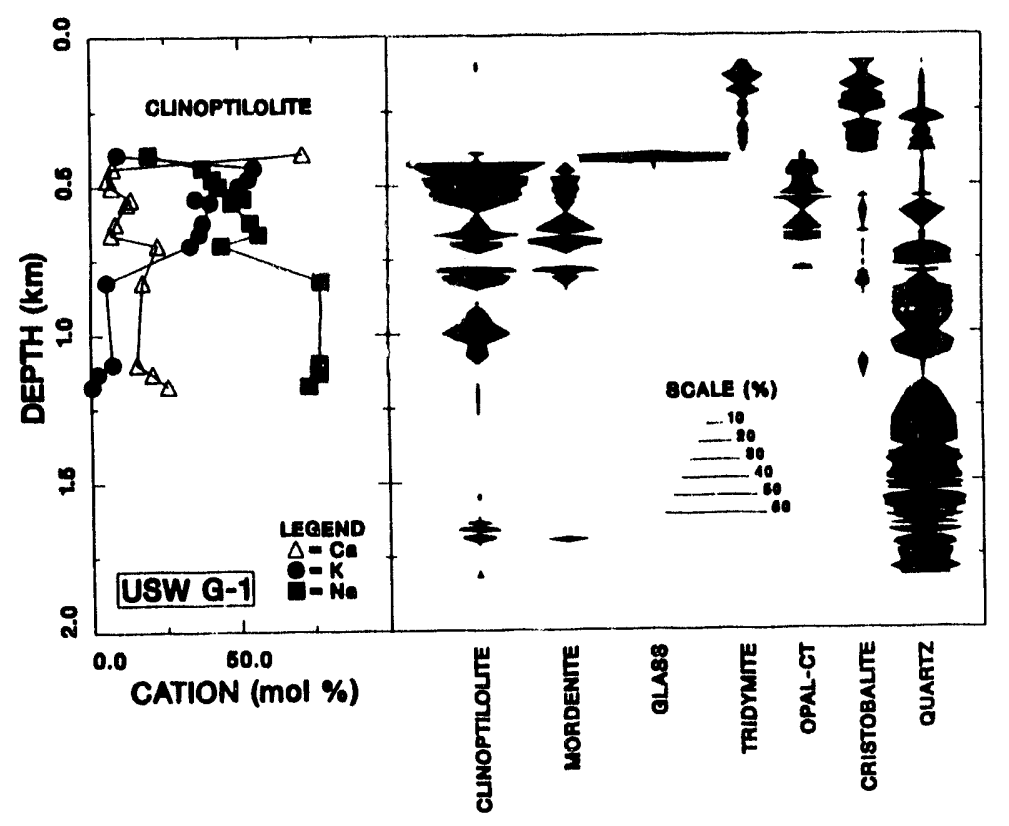

Fig. 10. Sodium, potassium, and calcium content of clinoptilolite and weight percentages of clinoptilolite, mordenite, glass and silica polymorphs in USW G-1.

$$
\begin{aligned}
& \mathrm{K}_{2.18} \mathrm{Al}_{2.18} \mathrm{Si}_{9.82} \mathrm{O}_{24} \rightarrow 2.18 \mathrm{KAlSi}_{3} \mathrm{O}_{8}+3.28 \mathrm{SiO} \\
& \text { K-clinoptilolite } \mathrm{K} \text {-feldspar aqueons silica }
\end{aligned}
$$

The water of hydration has not been included in this reaction or those that follow becanse of the lack of knowledge of the hydration state of the minerals containing water of hydration. Water is present throughout Yucca Mountain, so the availability of water should not limit the reactions. The activity of water will not be important in the esilibrium constants so long as the water is dilute. At the low temperatures of concern in Yucca Mountain, $\mathrm{K}$-feldspar is essentially a pure phase so the equilibrium constant for Eq. (11) is given by

$$
\Pi=\frac{a_{\mathrm{SiO}_{2(\mathrm{aq})}^{3}}^{28}}{x_{\mathrm{K}-\text { clinoptilolite }}}
$$

Fig. 22 shows the equilibrium mole fraction of $K$-clinoptilolite coexisting with

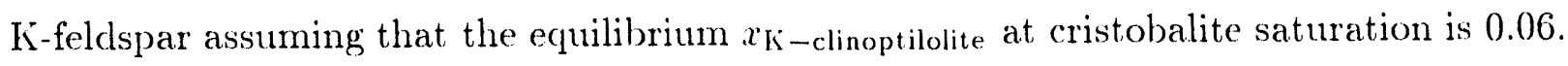
The diagram is calculated at $28^{\circ} \mathrm{C}$, but the relationship between the equilibrium $x_{\mathrm{K} \text {-clinoptilolite }}$ and the solubilities of the various silica polymorphs probably remains nearly constant over temperatures of importance in Yucca Mountain. Only the values of $a_{\mathrm{SiO}_{2(\mathrm{aq})}}$

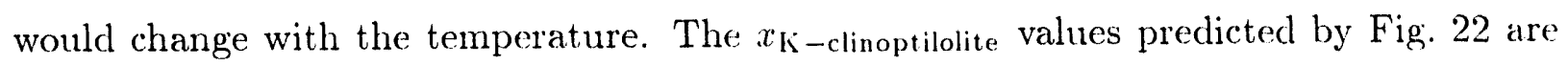




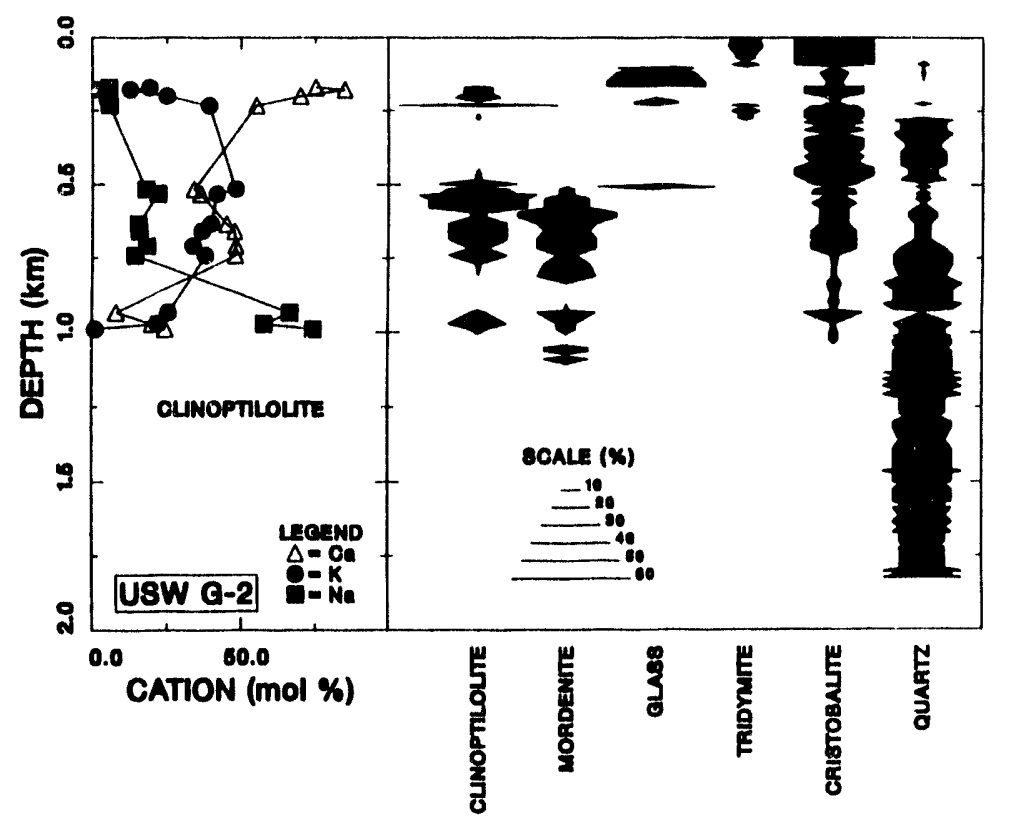

Fig. 11. Sodium, potassinm, and calciunn content of clinoptilolite ande woight percentages of clinoptilolite, mordenite, glass and silica polymorphs in USW G-2.

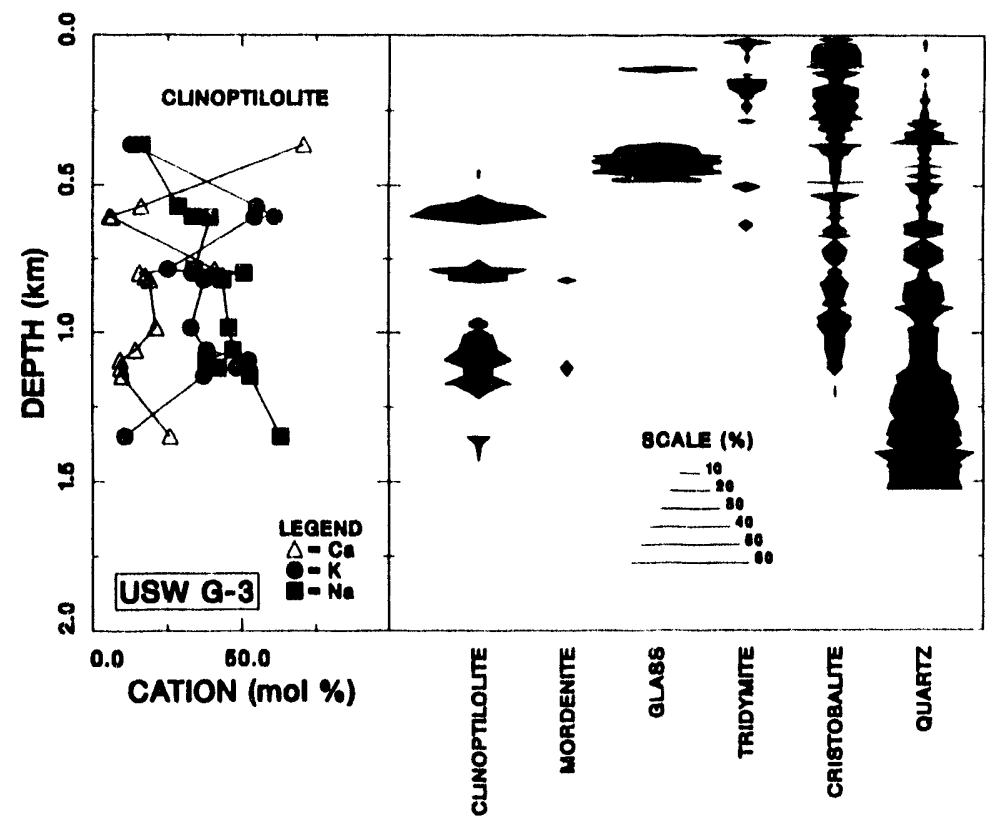

Fig. 12. Sodium, potassium, and calcium content of elinoptilolite and weight perechitages of clinoptilolite, morelenter, glass and silica polymorphs in USW G-3. 


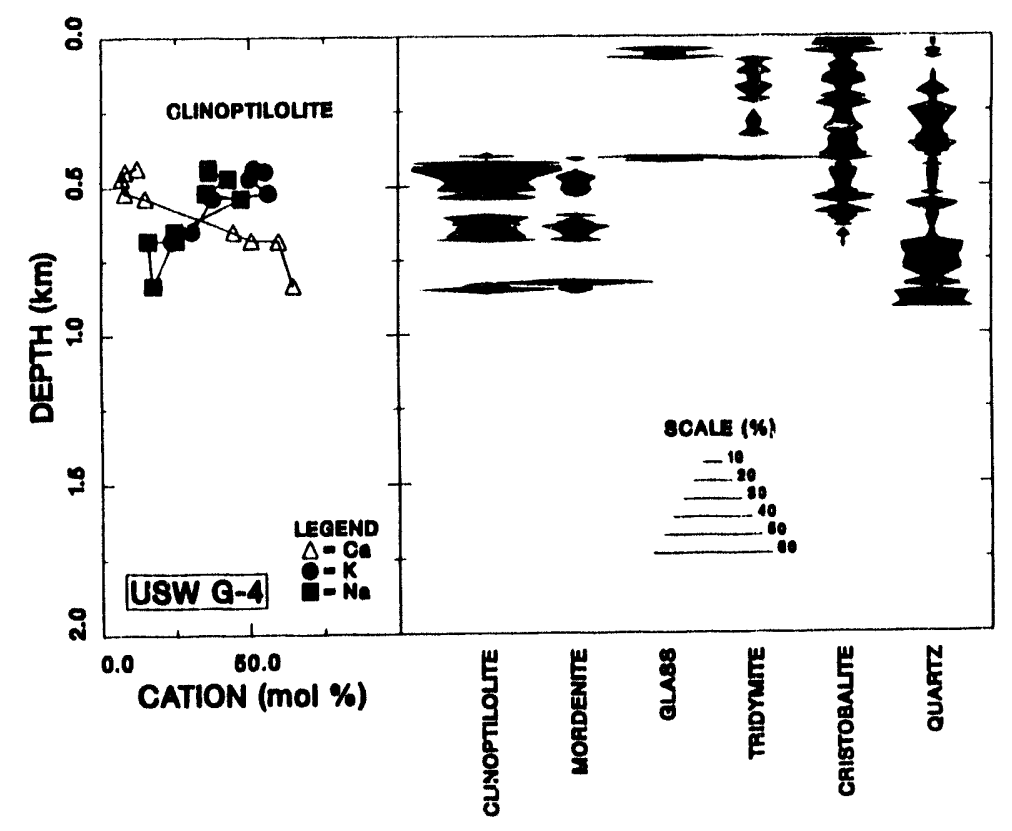

Fig. 13. Sorlium, potassium, and ralcium content of elinoptilolite and weight perecntages of elinoptilolite. mordenite, glass and silica polymorphs in USW G-4.

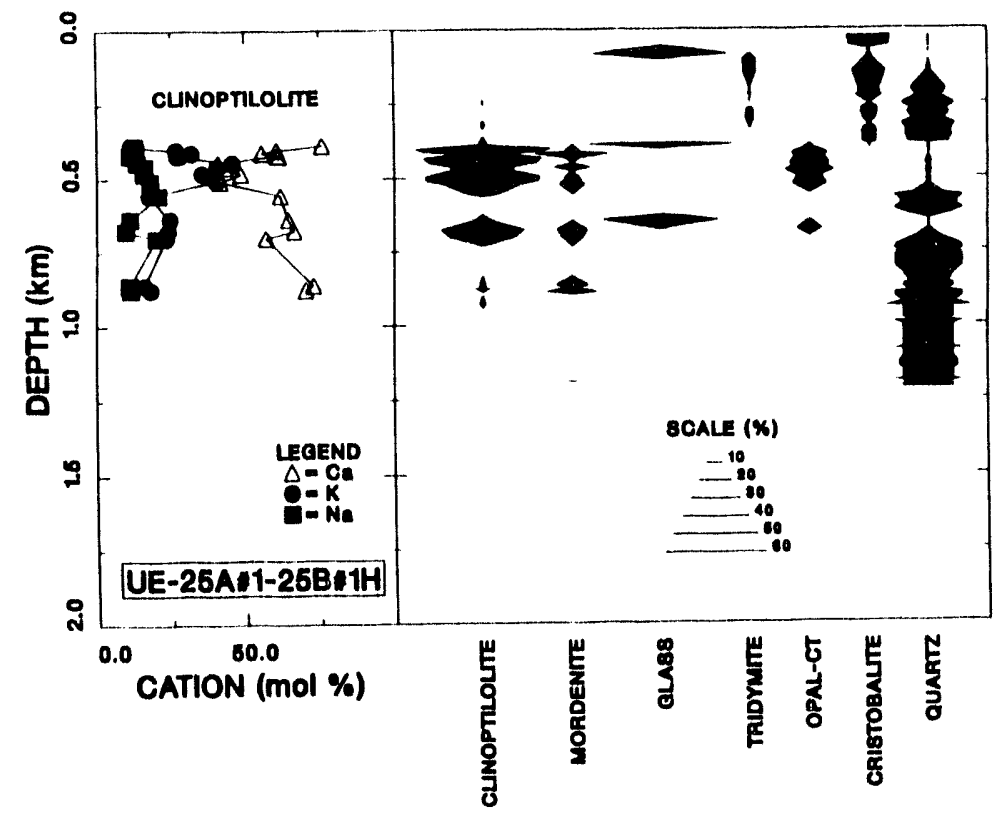

Fig. 14. Sodlium. potassium, and calcium content of clinoptilolite and weight percentages of clinoptelolite. mordenite, glass and silica polymorphs in UE-25a\#1 and UE-25l)\#1h. 


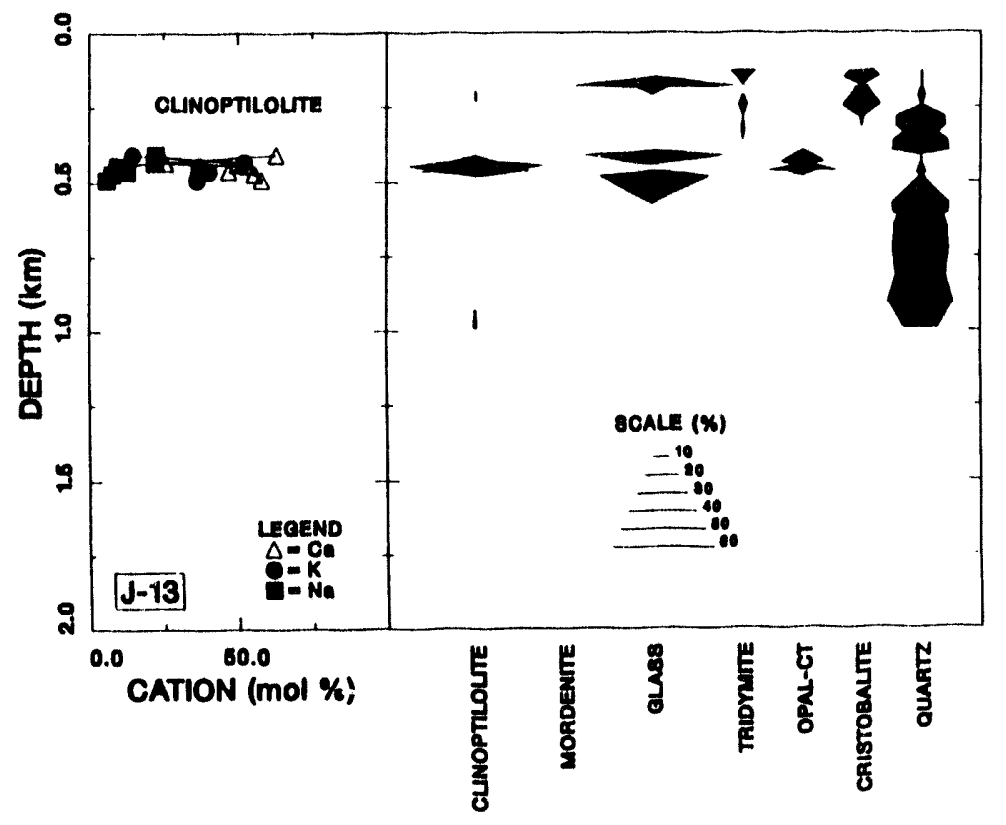

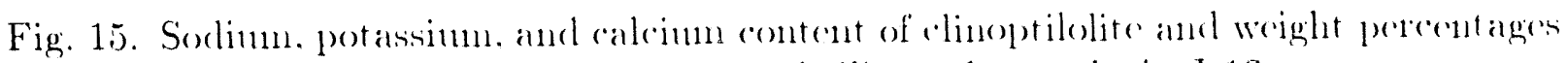
of chuoptilolite, morelenite. glass and silica polynorples in .J-13.

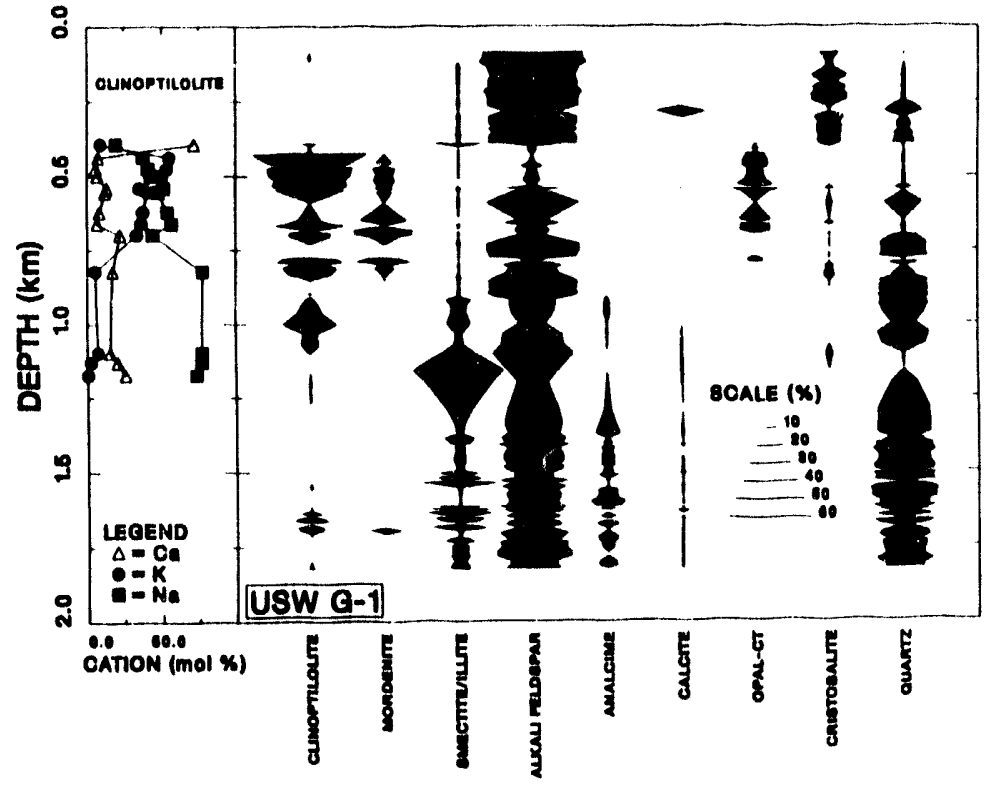

Fig. 16. Sodium, potassium, and aldeimu content of elinoptilolite and woight perecentages of minerals in USW G-1. 

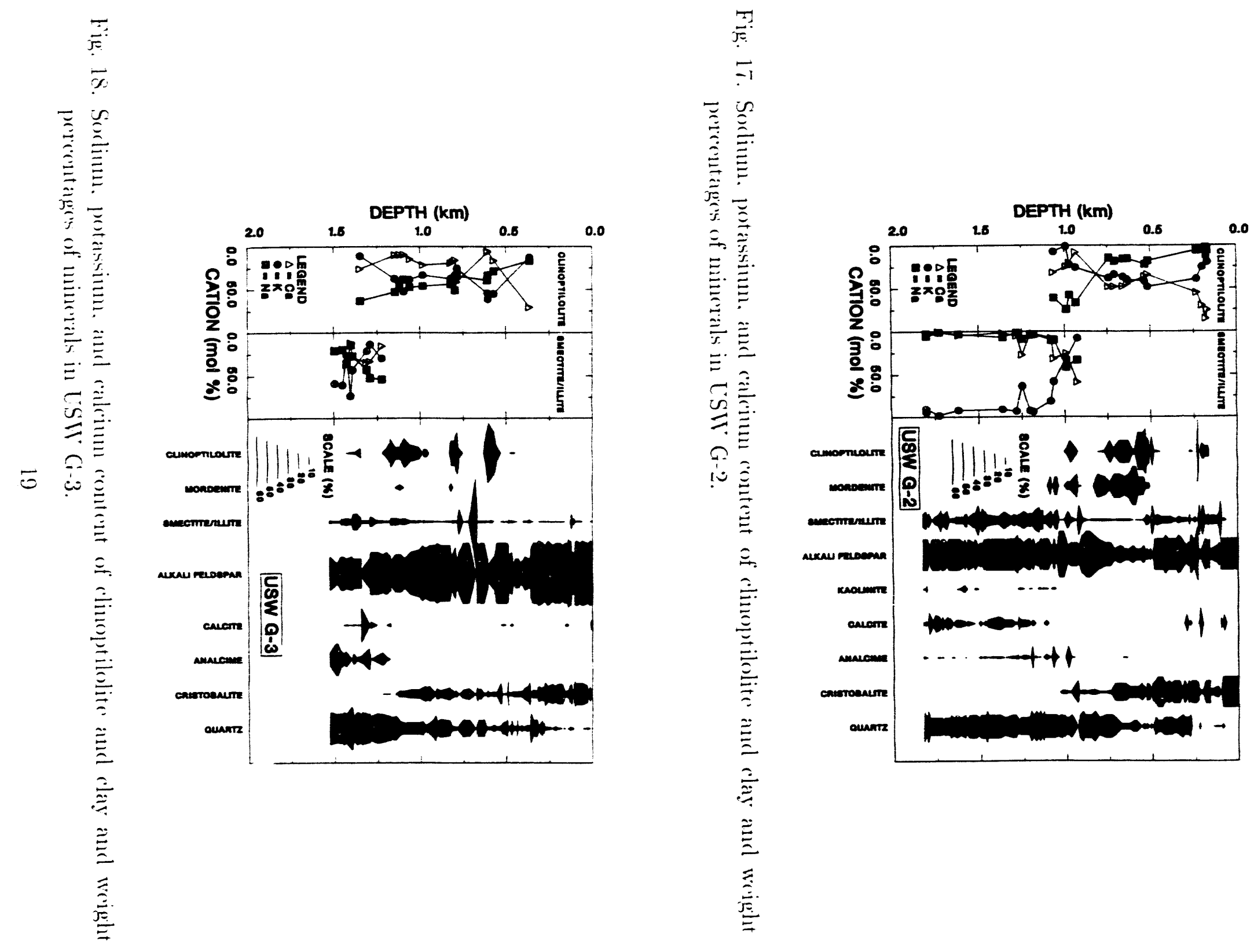


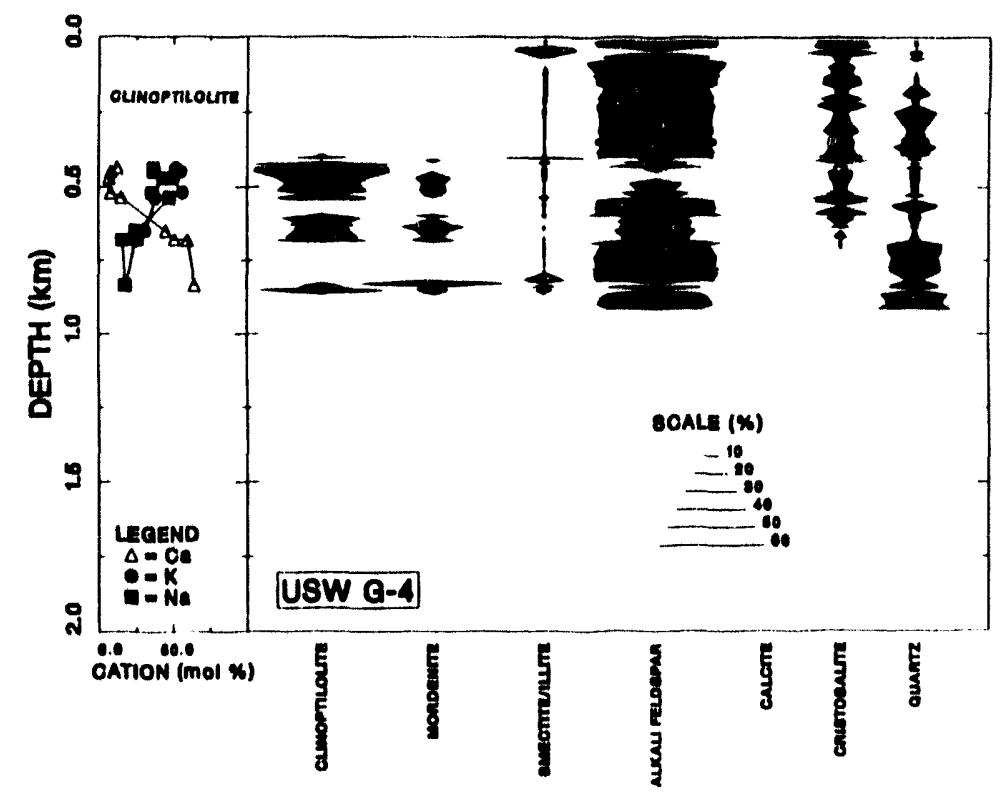

Fig. 19. Sorlinum. potassimun, and calcium content of clinoptilolite and woight perecentages of minerals in ISWV (i 4 .

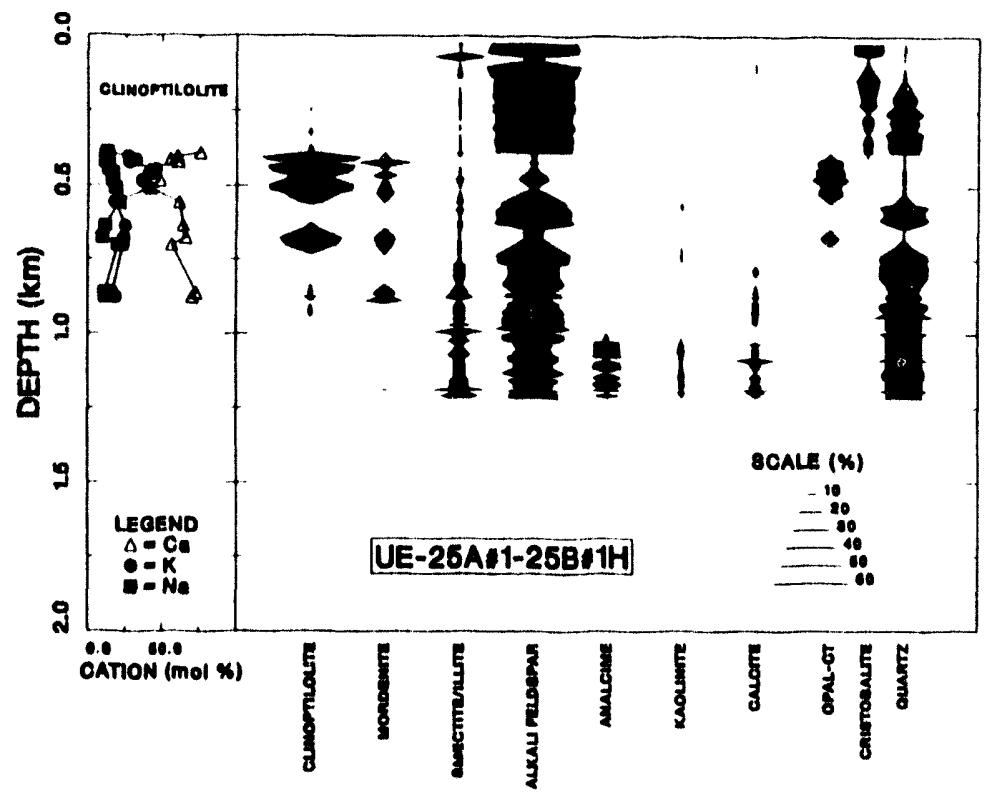

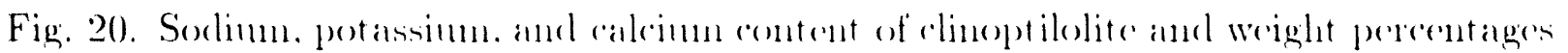

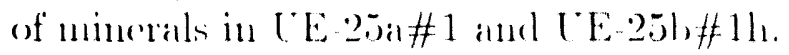




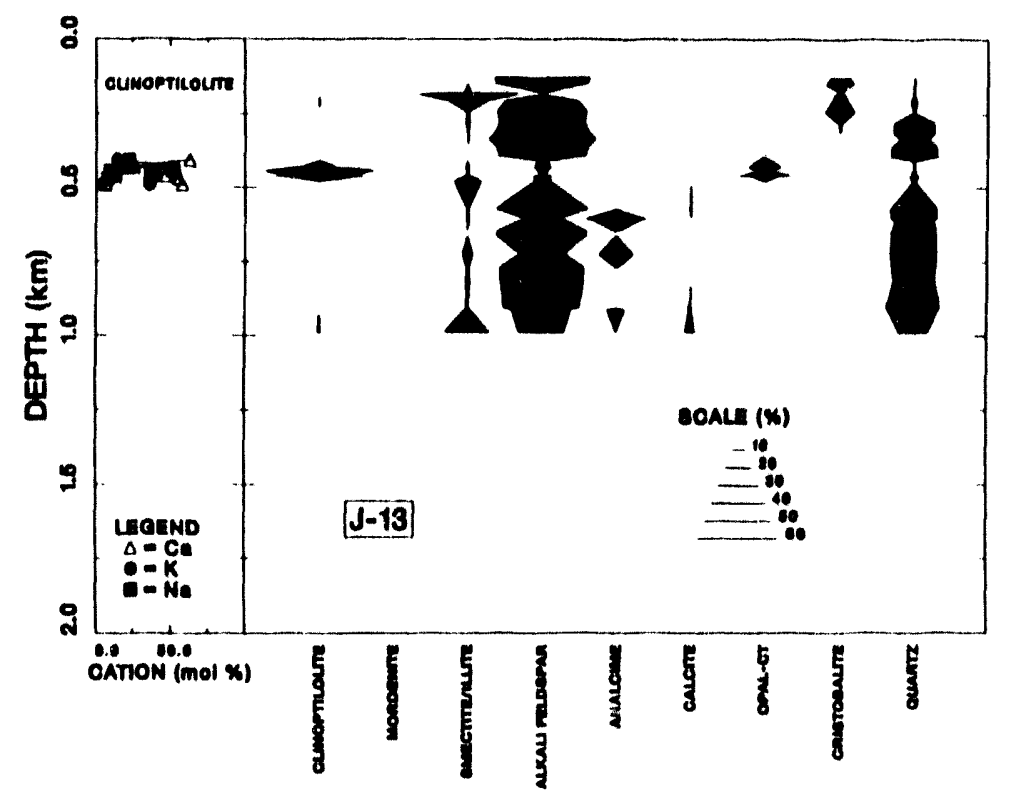

Fig. 21. Sollinm, potassinun, and caldeium content of elinoptilolite and woight percentages of mincrals in J-13.

consistent with the assmuption that $\left.a_{\text {sio }}\right)_{2(n)}$ is fixed at the solubility of the most soluble silien polymonple present, exeept perhaps in USW G-1 where only quartz is present with

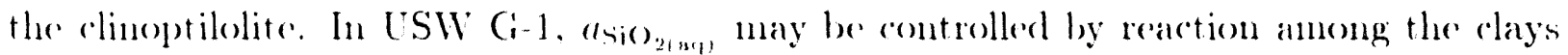
and acolites. Where clinoptilolite aoxists with opal-C'T, the potassium content of the rlinoptilolite gradually dererases with increasing depth. The kinetie morlel of the siliea polymorph transitions (to be presented later in detail) suggests that the depth distribution of silica polymorphs results from their temperature history with the nonweleled tuff in the npper part of the monutain experiencing nearly constant temperature near the present value. Fig. 23 presents the remults for a unoled with a constant temperature of $28^{\circ} \mathrm{C}$. The $28^{\circ} \mathrm{C}$ temperature of the model duplicates the current temperature at about $450 \mathrm{~m}$ in USW G-1 (Sass and Lachenbrueh, 1982) in the mpere part of the Tuff of Calieo Hills. The age of Calieo Hills tuff is about 13.4 111.y. (Marvin of al., 1970). The model predicts that the opal- C'T at this depth of $450 \mathrm{~m}$ womld have an 101 spareing ahout two-thirels of the way between highly disondered opal-C CT and cristobalite. Althongh the relationship) between 101 spacing and solubility is not known, the solubility of such an opal-CT is probably ronghly midway betwern that of "beta-cristobalite" and rristobalite, which would

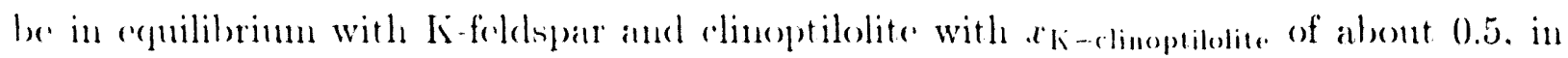
reasomable agrerement with the observed value of 0.08. 


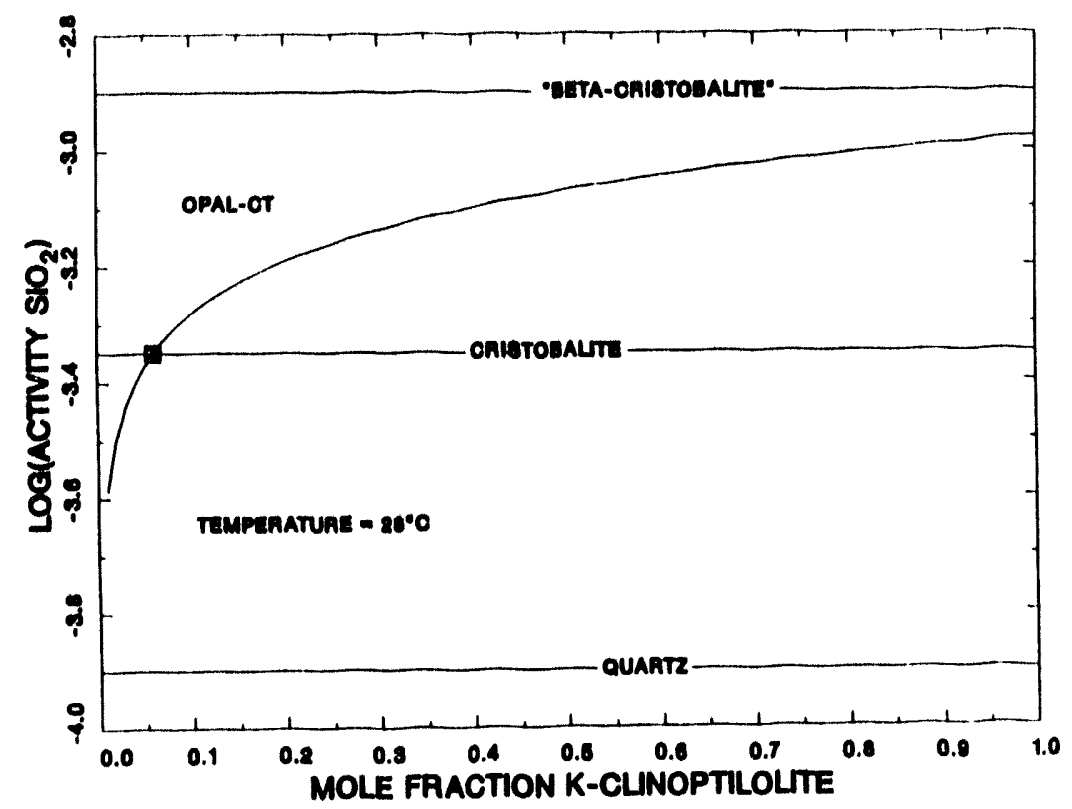

Fig. 22. Equilibrium $x_{K}$-clinoptilolite vs. $a_{\left.\mathrm{SiO}_{2 / \mathrm{aq}}\right)}$ for $\mathrm{E}_{(1} \cdot(11)$.

In USW G-1 and USW G-2, analcime begins to form when $x_{\text {Na-clinoptilolite rises to }}$ about 0.77 . The equation for this reaction is

$$
\underset{\text { Na-clinoptilolite }}{\mathrm{Na}_{2.18} \mathrm{Al}_{2}{ }_{18} \mathrm{Si}_{9.82} \mathrm{O}_{24}} \rightarrow \underset{\text { analcime }}{2.53 \mathrm{Na}_{86} \mathrm{Al}_{.86} \mathrm{Si}_{2.14} \mathrm{O}_{6}}+\underset{\text { aqueous silica }}{4.41 \mathrm{SiO}_{2}}
$$

Becanse analcine is a pure sodium phase,

$$
I=\frac{a_{\mathrm{SiO}_{2(\mathrm{a})}}^{4}}{l_{\mathrm{Na}}-\text { clinoptilelite }}
$$

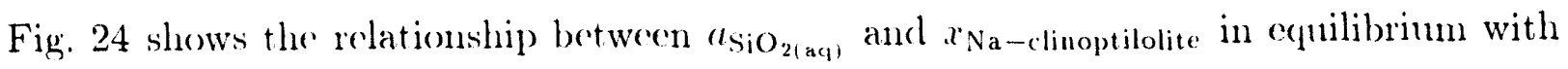
analcime based on Eq. (14) with the assumption that the equilibrium $r_{\text {Na-clinoptiblite at }}$ cristobalite saturation is 0.77 . The clineptilolite compositional data for USW G-3 suggest that $a_{\mathrm{SiO}_{2(a)}}$ is appreciably above cristobalite saturation, based on $x_{k \text {-clinoptilolite }}$ until cristobalite/opal-CT disappears from the hole. Below the disappearance of cristobalite. $x \mathrm{Na}$-clinoptilolite snggests that $a_{\left.\mathrm{SiO}_{2(\mathrm{a})}\right)}$ is slightly below cristobalite saturation, in agreement

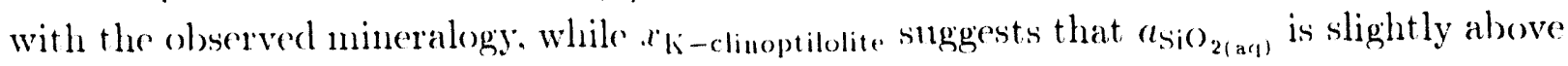
cristobalite saturation. In USTV G-4, UE-25a\#1-25b\#1h, and J-13, clinoptilolite does 


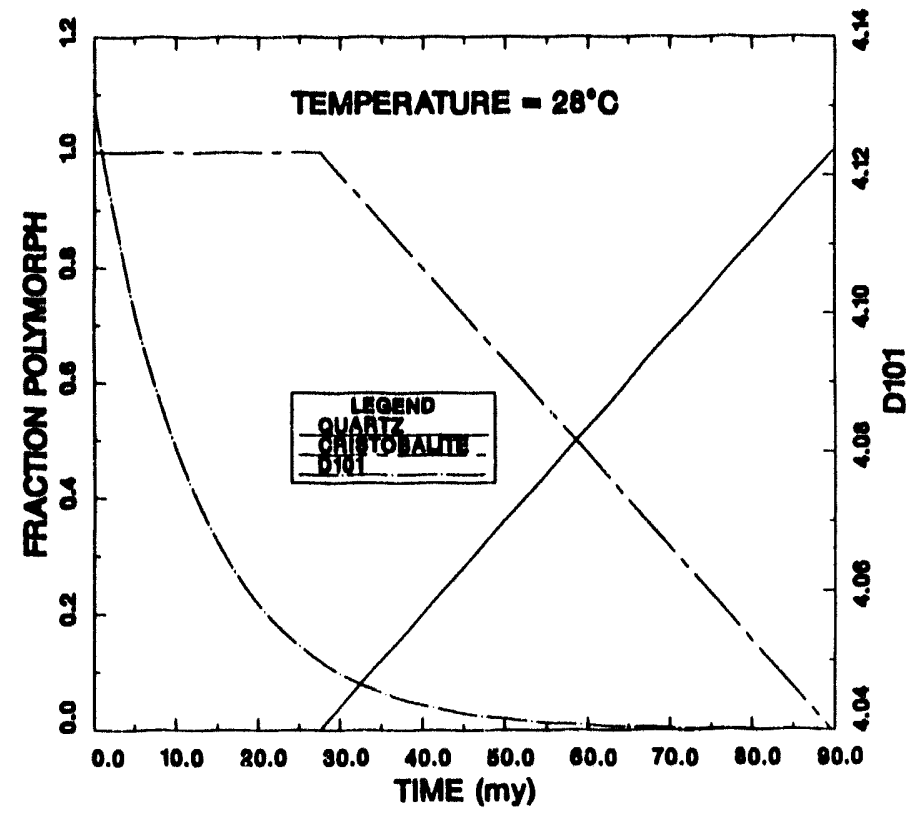

Fig. 23. Moclel prediction for the evolution of silica polymorphs at $28^{\circ} \mathrm{C}$. D101 is the spacing of the 101 planes in the crystal lattice of opal-CT.

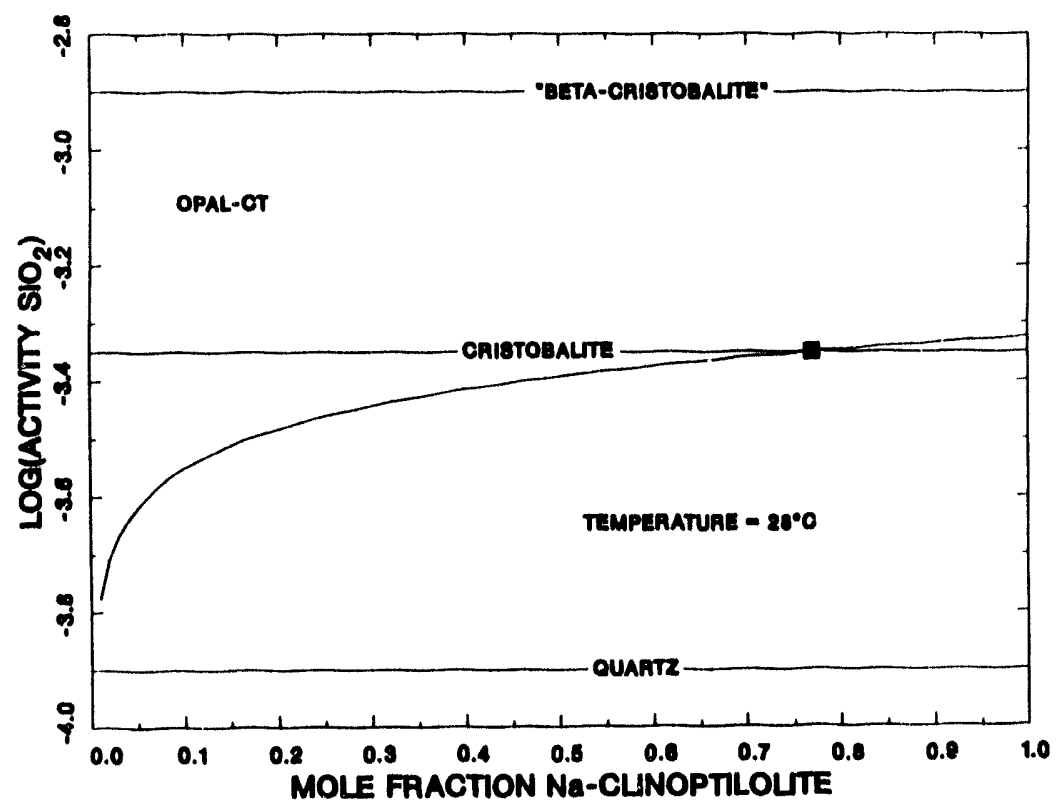

Fig. 24. Equilibrium $r_{\mathrm{Na}}$-clinoptilolite vs. $a_{\mathrm{SiO}_{2(\text { a } q)}}$ for $\mathrm{E}_{(1} \cdot(13)$ 
not coexist with analcime due to the low sodium content of the clinoptilolite. In these holes, the remaining clinoptilolite apparently transforms to suectite before sufficiently low $a_{\mathrm{SiO}_{2(\mathrm{aq})}}$ is reached for reaction to analcime.

The reaction of clinoptilolite to smectite can be described by the reactions

$$
\begin{aligned}
& \mathrm{Ca}_{1.09} \mathrm{Al}_{2.18} \mathrm{Si}_{9.82} \mathrm{O}_{24}+.59(\mathrm{Mg}, \mathrm{Fe}) \mathrm{O}+1.46 \mathrm{H}^{+}+0.73 \mathrm{CO}_{3}^{2-} \\
& \text { Ca-clinoptilolite } \\
& \rightarrow 0.66 \mathrm{Ca}_{.55}\left(\mathrm{Mg}, \underset{\mathrm{Fe}}{\mathrm{C} .9 \mathrm{Al}_{3.3} \mathrm{Si}_{7.8} \mathrm{O}_{20}(\mathrm{OH})_{4}+0.73 \mathrm{CaCO}_{3}+}+4.67 \mathrm{SiO}_{2}\right. \\
& \text { Ca-smectite }
\end{aligned}
$$

and

$$
\begin{aligned}
& \mathrm{Na}_{2.18} \mathrm{Al}_{2.18} \mathrm{Si}_{9.82} \mathrm{O}_{24}+1.98 \mathrm{Ca} .55\left(\mathrm{Mg}, \mathrm{Fo}_{.9} \mathrm{Al}_{3.3} \mathrm{Si}_{7.8} \mathrm{O}_{20}(\mathrm{OH})_{4}\right. \\
& \mathrm{Na} \text {-clinoptilolite Ca-smectite } \\
& \rightarrow \mathrm{Ca}_{1.09} \mathrm{Al}_{2.18} \mathrm{Si}_{9.82} \mathrm{O}_{2.4}+1.98 \mathrm{Na}_{1.1}(\mathrm{Mg}, \mathrm{Fe})_{.9} \mathrm{Al}_{3.3} \mathrm{Si}_{7.8} \mathrm{O}_{20}(\mathrm{OH})_{4} \\
& \text { Ca-clinoptilolite } \mathrm{Na} \text {-smectite }
\end{aligned}
$$

with equilibrium constants

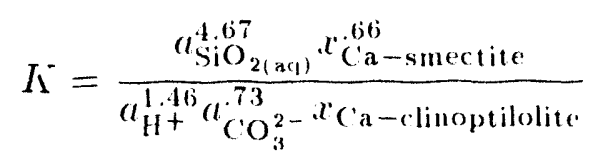

and

$$
K=\frac{x_{\mathrm{Ca}-\text { clinoptilolite }} \cdot r_{\mathrm{Na}-\text { smectite }}^{1.98}}{x_{\mathrm{Na}-\text { clinoptilolite }} \cdot l_{\mathrm{Ca}_{\mathrm{a}}^{1.9 m e c t i t e}}^{1.98}}
$$

An equation similar to E(1. (1T) could be written to describe exchange of potassium and calcium between clinoptilolite and smectite, but little potassium remains in the clinoptilolite when the transformation to smectite occurs.

Equation (17) shows that the transformation of clinoptilolite to snectite is highly dependent on $a_{\mathrm{SiO}_{2(\mathrm{aq})}}$, but is also dependent on the $\mathrm{pH}$ and $a_{\left(\mathrm{C}_{3}\right.} \mathrm{O}^{-}$. The progress of 
Eq. (15) is limited by the supply of $\mathrm{CO}_{3}^{2-}$. As the reaction proceeds, $a_{\mathrm{CO}_{3}^{2-}}$ will fall until the reaction stops unless additional $\mathrm{CO}_{3}^{2-}$ is brought into the rock by moving water. The supply of iron and magnesium could also limit this reaction. Although small amounts of iron and magnesium are found in the clinoptilolite, they are sufficient for the formation of only very small amounts of smectite. Sufficient additional iron and magnesium are apparently available for the complete transformation of clinoptilolite. Iron is probably present as iron oxides and hydroxides; some of the magnesium may also be present as oxides and hydroxides, although the form of magnesium in the high clinoptilolite rocks is unclear. To the extent that magnesium is present in aluminum silicates, the amount of calcite produced in $\mathrm{Eq}$. (15) will be reduced.

Althoing $\mathrm{Eq}_{\mathrm{q}}$. (15) is dependent on $a_{\mathrm{CO}_{3}^{2-}}$ and $\mathrm{pH}$, the process is much more dependent on $a_{\mathrm{SiO}_{2(\mathrm{aq})}}$ because of the larger exponent of $a_{\mathrm{SiO}_{2(\mathrm{aq})}}$ in (17). Because of the complex interplay of parameters affecting this reaction, more detailed numerical modeling is needed. Smectite generally coexists with clinoptilolite in Yucca Mountain, but appreciable clinoptilolite reaction to form smectite appears to happen only at $a_{\mathrm{SiO}_{2(\mathrm{aq})}}$ near cristobalite saturation. Varying $a_{\mathrm{CO}_{3}^{2}}$ with $a_{\left.\mathrm{SiO}_{2(a)}\right)}$ near cristobalite saturation probably changes the calcinm/sodium partitioning between coexisting clinoptilolite and smectite. Equation (17) indicates that at higher $a_{\mathrm{CO}_{3}^{2-}}$ the smectite will become more calcium rich and the clinostilolite less calcium rich. Equation (18) inclicates that the converse will be true for sodium.

The uppermost clinoptilolites in Yucca Mountain tend to be calcium rich. While the rock in which these clinoptilolites occur tends also to be calcium rich, this is not universally true as in UE-25a\#1. These clinoptilolites have low potassium contents indicative of $a_{\mathrm{SiO}_{2(\mathrm{aq})}}$ near cristobalite saturation. The low $a_{\mathrm{SiO}_{2(\mathrm{aq})}}$ is probably caused by equilibration of the water with immediately overlying tridymite- and cristobalite-bearing rocks as the water moves downward. These clinoptilolites generally occur with smectite. The high calcium content probably results from low $a_{\mathrm{CO}_{3}^{2-}}$. Low values of $a_{\mathrm{CO}_{3}^{2-}}$ probably result from limited water movement in the unsaturated zone where these clinoptilolites occur and from the depletion of the limited supply of $\mathrm{CO}_{3}^{2-}$ by the reaction shown in Eq. (15). As $\mathrm{Eq}$. (15) proceeds, $\mathrm{H}^{+}$is depleted, reinforcing the effect of $\mathrm{CO}_{3}^{2-}$ depletion. Calcite, predicted as a product of this reaction, has not generally been observed in these rocks, except in USW G-2; however it has been observed in the uppermost clinoptilolite zone of USW G-2. Calcite may not have been observed either because of its tendency to be mobile and form vein fillings or because of low abundance. Equation (15) predicts that 
about $0.15 \mathrm{wt} \%$ calcite will be formed for every weight percent Ca-smectite. Considering that $x_{\mathrm{Ca}-\text { smectite }}$ will probably be less, perhaps considerably less, than 0.5 , less than 2 wt $\%$ calcite would be expected to result from formation of $30 \mathrm{wt} \%$ smectite. A more detailed understanding of this reaction may provide a means of estimating the water flux through this zone.

A similar $\mathrm{CO}_{3}^{2-}$ limited reaction of clinoptilolite to smectite appears to occur in the lower portions of the clinoptilolite zone in USW G-4, UE-25a\#1-25b\#1h, and J-13 after opal-CT disappears. However, in USW G-1, USW G-2, and USW G-3, $x_{\text {Ca-clinoptilolite }}$

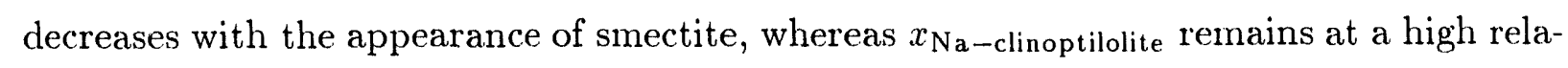
tively constant value that is probably controlled by equilibrium with analcime. The lower

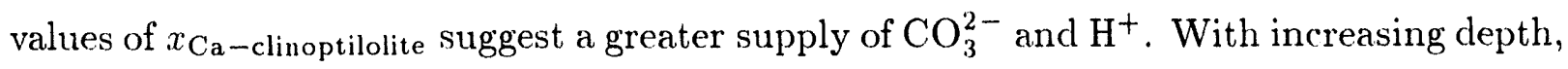
$x_{\mathrm{Ca}-\text { clinoptilolite }}$ increases and $x_{\mathrm{Ca} \text {-smectite }}$ decreases where smectite and clinoptilolite coexist. This trend probably results from decreasing $a_{\mathrm{SiO}_{2(\text { aq) }}}$ with depth.

Smectite analyses are available only for USW G-2 and USW G-3. These smectites show a trend of increasing potassium and decreasing sodium and calcium content with increasing depth. This trend, particularly obvious in USW G-2, corresponds to a transition from smectite to illite (Caporuscio et al., 1982). However, the nature of the smectite/illite transition is somewhat uncertain. The smectite/illite transition takes place in pelitic sediments in the temperature range from about 60 to $150^{\circ} \mathrm{C}$. However, the extent of conversion of smectite to illite layers can vary even at a given temperature (Perry and Hower, 1972; Bruce 1984). It is not known whether the observed extent of reaction reflects a difference in pressure, pore fluid composition, bulk chemistry of the shale, or composition of the starting smectite or whether it is a time effect reflecting the kinetics of the reaction (Eberl and Hower, 1976; Roberson and Lahann, 1981). The complexity of the problem increases with the uncertainty as to the correct thermodynamic representation for mixed layer smectite/illite. Zen (1962) pointed out that either a solid solution or a two-phase aggregate representation of smectite/illite may be correct. This uncertainty remains unresolved. Aagaard and Helgeson (1983) have used a solid solution model, whereas Garrels (1984), using the same data set, treats the montmorillonite and illite interlayers as separate phases.

It seems likely that aqueous silica activities substantially above quartz saturation are in equilibrium with highly smectitic clays. This conclusion is consistent with both Aagaard and Helgeson (1983) and Garrels (1984). The Garrels' model, treating montmorillonite and illite as separate phases, indicates that at $25^{\circ} \mathrm{C}$ the transition takes place abont midway, on a logarithmic scale, between quartz and amorphous silica saturation. Although the 
aqueous silica activity for the transition will increase with increasing temperature, its relationship to the solubility of quartz should remain approximately constant. For the aqueous silica activity to remain high, as indicated by the water composition clata compiled by Aagaard and Helgeson (1983), the clay reaction rate must be faster than that for quartz precipitation. The rate of montmorillonite to illite conversion will then be cletermined by the rate of quartz precipitation. Such a model explains the broad temperature range in which the observed smectite/illite conversion takes place (Hower, 1981; Bruce, 1984) and explains the observed variation of the temperature dependence on time of burial. The model does not explain why the transition stops with approximately $20 \%$ smectite layers remaining.

However, if we use the solid solution model (Aagaard and Helgeson, 1983) for smectite/illite, the smectite/illite reaction can proceed at equilibrium as the aqueous silica activity in equilibrium with the clay decreases. The model (Aagaard and Helgeson, 1983) suggests that complete conversion to illite is achieved before cluart\% saturation is reached. Uncertainties in both the model and the thermodynamie data allow that the smectite/illite reaction stops at $20 \%$ montmorillonite layers when it comes into equilibrium with quartz. The conversion rate of montmorillonite to illite layers would still be cletermined by the rate of quartz precipitation: however, as the acueous silica activity procluced by the clay reaction approached quartz saturation. the quartz precipitation rate would approach zero and the smectite to illite reaction would stop.

Assuming that smectite/illite can be represented by a solicl solution of C'a-smectite, Na-smectite, and Ki-illite endmembers, reactions anong the endmembers can be described by

$$
\begin{aligned}
& \text { 1.9KAlSi. } \mathrm{O}_{8}+\mathrm{Ca}_{.5 .5}\left(\mathrm{Mg}, \mathrm{Fr}_{.9} \mathrm{Al}_{3.3} \mathrm{Si}_{7.8}\left(\mathrm{O}_{20}(\mathrm{OH})_{4}\right.\right. \\
& \mathrm{K} \text {-feldspar ('a-smectite } \\
& +1.1 \mathrm{H}^{+}+0.55 \mathrm{CO}_{3}^{2-} \\
& \left.\rightarrow \mathrm{K}_{1.9}(\mathrm{Mg}, \mathrm{Fc})_{.9} \mathrm{Al}_{4.1} \mathrm{Si}_{7} \mathrm{O}_{20}(\mathrm{OH})_{4}+0.55 \mathrm{CaC}^{\prime}\right)_{3} \\
& \text { li-illite calcite } \\
& +0.28 \mathrm{Al}_{4} \mathrm{Si}_{4} \mathrm{O}_{10}(\mathrm{OH})_{8}+5.38 \mathrm{SiO}_{2} \\
& \text { Kaolinite aqueous silica }
\end{aligned}
$$

and 


$$
\begin{aligned}
& \text { 1.9KAlSi } \mathrm{O}_{3}+\mathrm{Na}_{1.1}(\mathrm{Mg}, \mathrm{Fe})_{.9} \mathrm{Al}_{3.3} \mathrm{Si}_{7.8} \mathrm{O}_{20}(\mathrm{OH})_{4}+ \\
& \mathrm{K} \text {-feldspar } \\
& \mathrm{Na} \text {-smectite } \\
& \rightarrow \mathrm{K}_{1.9}(\mathrm{Mg}, \mathrm{Fe})_{.9} \mathrm{Al}_{4.1} \mathrm{Si}_{7} \mathrm{O}_{20}(\mathrm{OH})_{4} \\
& \mathrm{~K} \text {-illite } \\
& +1.28 \mathrm{Na}_{.86} \mathrm{Al}_{.86} \mathrm{Si}_{2.14} \mathrm{O}_{6}+3.76 \mathrm{SiO}_{2} \\
& \text { analcime } \\
& \text { aqueous silica }
\end{aligned}
$$

with equilibrium constants

$$
K=\frac{a_{\mathrm{SiO}_{2(\mathrm{aq})}^{5.38}}^{5 . \text { illite }}}{a_{\mathrm{H}+}^{1.1} a_{\mathrm{CO}_{3}^{2-}}^{.55} x_{\mathrm{Ca}-\text { smectite }}}
$$

and

$$
\Pi=\frac{a_{\mathrm{SiO}_{2(\mathrm{aq})}}^{3.76} x_{\mathrm{K}-\mathrm{illite}}}{x_{\mathrm{Na}-\text { smectite }}}
$$

These reactions show that the observed progression of minerals with depth below the clinoptilolite zones can also be explained by decreasing $a_{\left.\mathrm{SiO}_{2(\mathrm{a})}\right)}$. Kaolinite is present and calcite is most abundant in USW G-2 and UE-25b\#1h where conversion to illite is nearly complete (Caporuscio et al., 1982). Analcime is generally more abundant at increasing depth, but tends to diminish in the illite zone of USW G-2. This is probably due to the replacement of analcime by albite for which the reaction is

$$
\underset{\text { analcime }}{\mathrm{Na} .86 \mathrm{Al}_{.86} \mathrm{Si}_{2.14}}+\underset{\text { aqueous silica }}{0.44 \mathrm{SiO}_{2}} \rightarrow 0.86 \mathrm{NaAlSi}_{3} \mathrm{O}_{8}
$$

The equilibrium constant for this reaction is

$$
K=a_{\left.\mathrm{SiO}_{2(\mathrm{ar})}\right)}^{44}
$$

so there should be a particular $a_{\mathrm{SiO}_{2(\text { aq })}}$ at which analcime transforms to albite. The exact form of the equilibrium constant and $a_{\mathrm{SiO}_{2(\text { aq })}}$ depends on the $\mathrm{Al} / \mathrm{Si}$ ratio of the analcime. More importantly Eq. (24) predicts that allite should be stable at higher $a_{\left.\mathrm{SiO}_{2(\mathrm{a})}\right)}$ than 
analeine, which is contrary to the assumption that asio ${ }_{2(n+1)}$ dereases with depth in Yueca Momntain. Albite with a high degree of aluminum/silicon orelering (the stable form at low

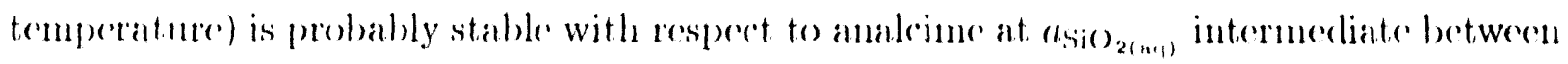
cristobalite and quartz saturation (Duffy, 1985). However, it appoas that the highly orelered form lats diffienlty crystallizing at low temperature. Albite that is more disordered combl form more anily, but is not stable with respere to analeime at low temperature.

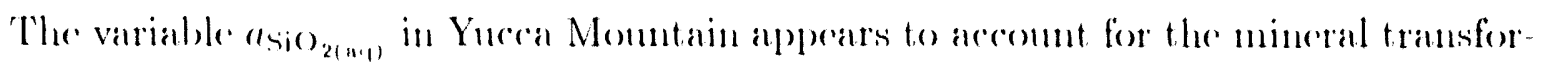
mations that have been observerl. ()nly the stability of mordenite has not been considered. Morelenite stability is difficult to examine beranse of the limited information on its composition. The limited compositional data available suggest that the equilibria betweren clinoptilolite and mordenite and be described by the reactions

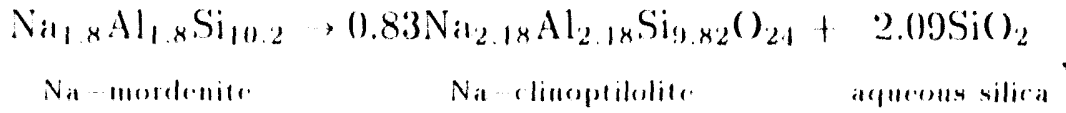

$$
\begin{aligned}
& \mathrm{K}_{1 . \times} \mathrm{Al}_{1.8} \mathrm{Si}_{111.2} \rightarrow 0.83 \mathrm{~K}_{2.1 \times} \mathrm{A \textrm {I } _ { 2 . 1 \times }} \mathrm{Si}_{9.82}\left(\mathrm{O}_{2.4}+2.09 \mathrm{Si}_{2}\right.
\end{aligned}
$$

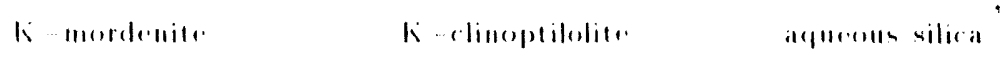

a111

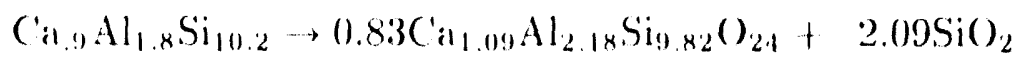

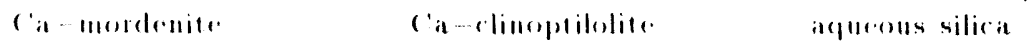

The erpuilibrimu comstants for these reactions have the general form

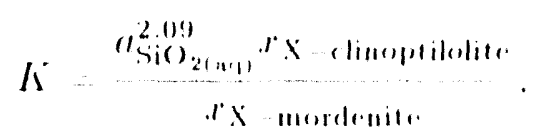

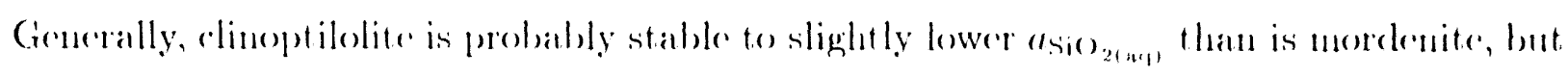
this may vary with bulk composition. As noterl andier, morelenitr probably contains more sodium than does coexisting clineptilolite. Beranse of this, morelenite might remain stable

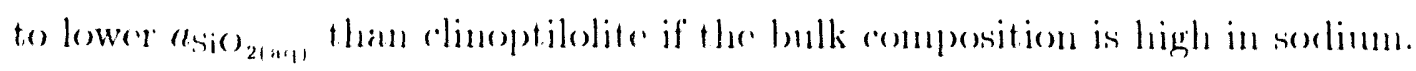

\section{REAC'TION RA'TES}

Both water chemistry and mineral distribution in Furan Momutain appear to be con sistent with the assmunt ions that the solubility of the most soluhle silica polymorph present 
in a given location controls $a_{\mathrm{Si}()_{3(\mathrm{Aq})}}$ and that changing $a_{\mathrm{SiO}_{2(\mathrm{aq})}}$ largely controls the observed mineral transitions in Yucca Mountain. The metastable state of silica polymorphs in Yucra Mountain implies that mineral alteration is an ongoing process. However, the rate at which reactions can proceed is linited by the rate of transformation of the silica polymorphs. Several factors such as pressure, $\mathrm{pH}$, and temperature are known to affect the rate of silica polymorph transitions, but only temperature can be quantified at this time. Duffy (1993) describes in detail the kinetic model used here. The model assumes that the transitions from disordered opal-CT to quartz occur in a stepwise manner. Disordered opal-C'T transforms to ordered opal-CT, which is nearly equivalent to cristobalite, through a solid state reaction. A clecrease in the 101 spacing in the crystal lattice of opal-CT reflects the progress of this reaction. When the 101 spacing reaches $4.05 \AA$, transformation of the ordered opal-CT/cristobalite to quartz begins by means of a dissolution/precipitation reaction. This reaction sequence agrees with the $x$-ray diffraction data of Bish and Chipera (1986), where little quartz was found coexisting with opal-CT, while considerable quartz was present with cristobalite. Even the small amounts of quartz present with opal-CT may be primary phenocrysts that did not form from opal-CT.

The rate equation for the ordering of opal-CT is

$$
\frac{d S}{d t}=-k S
$$

where

$$
S=d(101)-4.040 \mathrm{~A}
$$

$t$ is the reaction time and $k$ is the rate constant. The rate equation for the transformation of ordered opal-('T/eristobalite to quarty is

$$
\frac{d C_{r}}{d t}=-k
$$

where $C^{\prime}$, is the ratio of cristobalite/(cristobalite + quarty). The dependence of the rate constants on temperature is given by

$$
k=A c^{-E / R T}
$$


where $A$ is the frequency factor, $E$ is the activation energy, $R$ is the gas constant, and $T$ is the temperature in kelvin. The frequency factors and activation energies for Eqs. (29) and (31) are given in Table II.

\section{TABLE II}

\begin{tabular}{lcll}
$A\left(\mathrm{yr}^{-1}\right)$ & $E(\mathrm{kcal} / \mathrm{mol}$, & \multicolumn{1}{c}{ Reaction } & \multicolumn{1}{c}{ Reforence } \\
$2.62 \cdot 10^{7}$ & 20. & Ordering of (Opal-CT & Kano (1983) \\
$1.11 \cdot 10^{9}$ & 23.2 & Opal-CT/Quart\% & Erust \& Calvert (1969)
\end{tabular}

Duffy (1993) observed that these equations prediet disappenanee of opal-CT and cristobalite near the depths observed in Yucen Monntain if the present temperature distribution existed thenghout the lifetime of the rocks. Based on clay mincralogy. Caporuscio ot al. (1982) and Bish and Semarge (1982) snggest temperatures as high as $200^{\circ} \mathrm{C}^{\prime}$ may have been attained in the past at the bottom of USW Ci-2. The model that has been presented here does not assume that elevated temperatme is neeressary for the formation

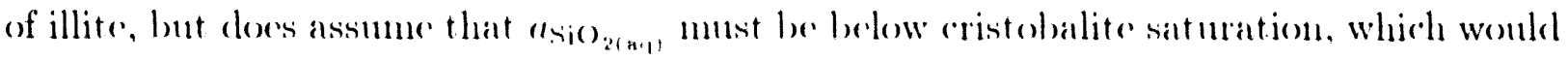
recuire that the only remaining silica polymorph is guart\%. Highly illitic elay is present at depth in USW G-2 (Capornsede ot al. 1982) and near the bottom of USW G-1, where only quartz is present. However, illites from 1181 and $1576 m$ in USW G-2 and $1718 \mathrm{~m}$ in USW G-1 have $K$-Ar dates of $10.9 \pm 0.6$ m.y. (Broxton et al., 1987) (sample depths provided by David L. Bish. persomal communication). This $\mathrm{K}$-Ar date is contemporaneons with the younger aruptions from 11.3 to $9.5 \mathrm{~m}$.y. (Marvin ot al., 1970) of the Timber Momintain-Oasis Valley caldera complex located north of Yinca Momutain. Transformation of metastable polymorphs to quartz at 10.9 m.y. may have been cansed by a heating event associated with these eruptions.

Fig. 25 shows the model calculation of the crolution of silica polymorphs at $85^{\circ} \mathrm{C}$, starting with all of the silica present as disordered opal-C T with a 101 lattice spacing of $4.13 \AA$. I predict the complete conversion to quart:z to recquire about $0.26 \mathrm{~m} . \mathrm{y}$., which is in reasonable agreenent with the 0.4 1n.y. difference in time between the age of the beginning of the ash-How rycles of the Timber Monutain Tuff and the most probable time for crystallization of the illite. This time span conld possibly have bern o to greater than 1 m.y. Adequate data do not exist to determine a precise temperature history for the drill holes in Yueca Monntain, but two possible temperature histories have been examined. The 


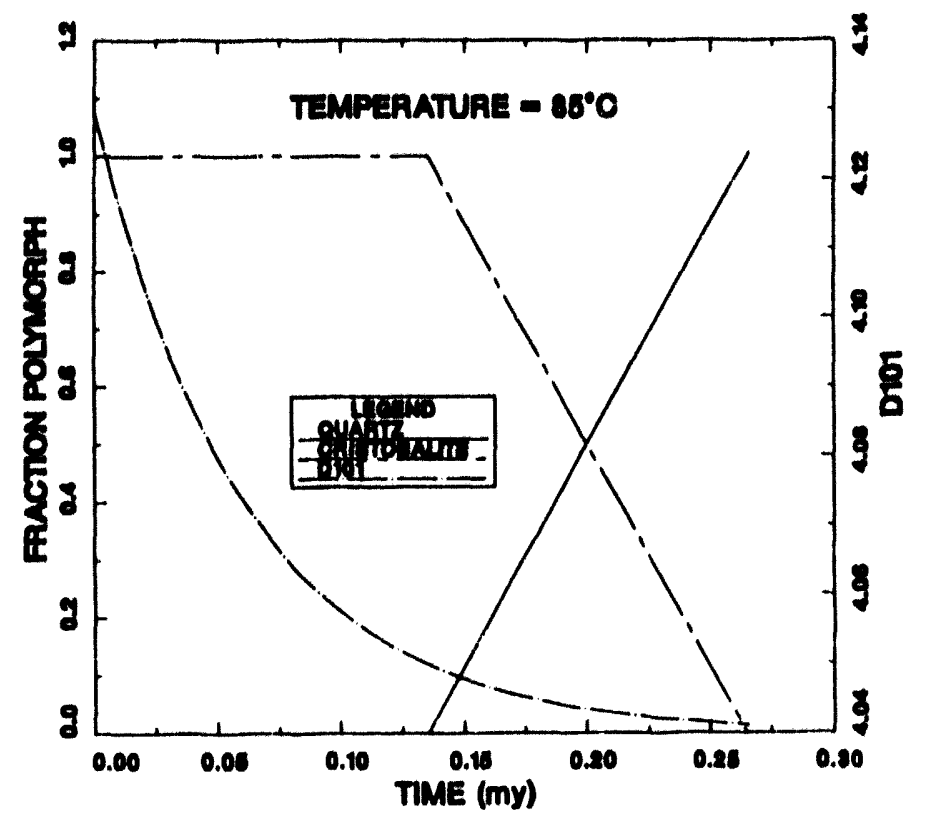

Fig. 25. Model prediction for the evolution of silica polymorphs at $85^{\circ} \mathrm{C}$. D101 is the spacing of the 101 planes in the crystal lattice of opal-C'T.

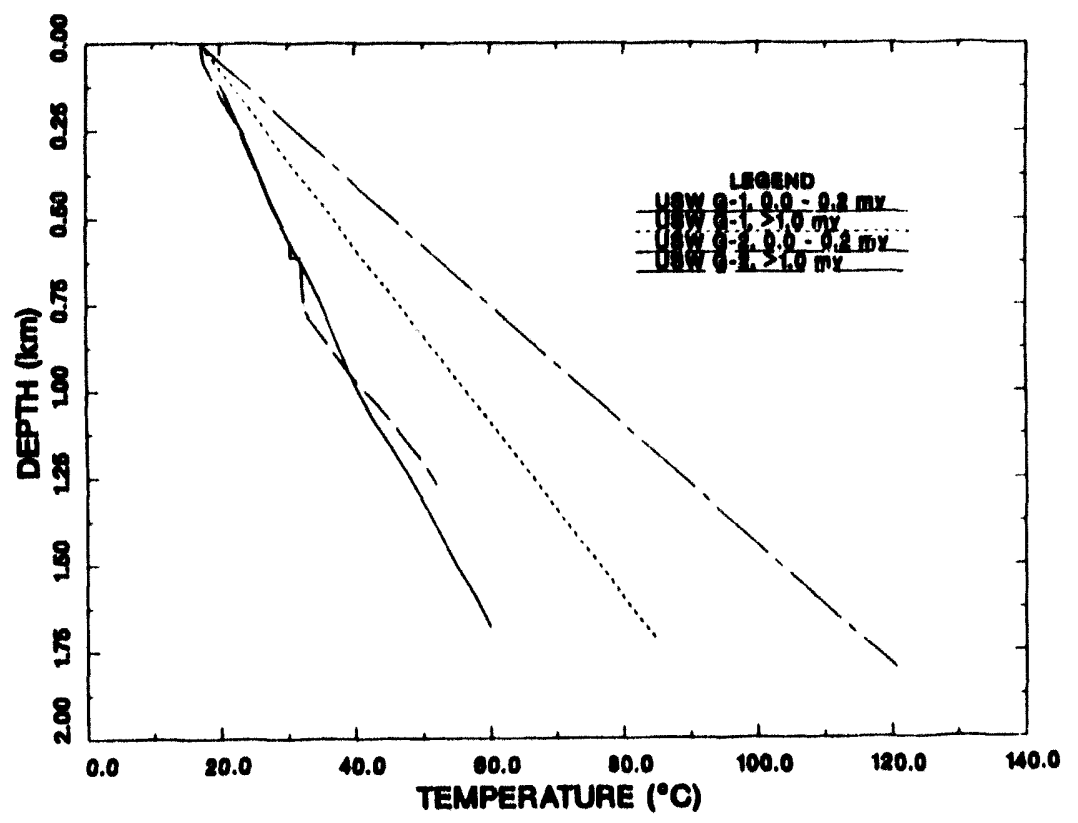

Fig. 26. Morlel temperature histories for USW G-1 and USW G-2. 
first temperature history, illustrated in Fig. 26, shows the present-rlay temperature profile for USW (i-1 (Sass and Lachenhruch, 1982) and for USW G-2 (Sass et al., 1983). I assmue that the temperature rose to $85^{\circ} \mathrm{C}$ at the initial time at the position of the mpermost cated illite, that is at 1181-m depth in USW G 2 and at 1718 m in USW G-1. I assume a linene temperature gradient to the sufface, which remains at the current surface temperature. This enemperature distribution remains constant for $0.2 \mathrm{~m} . y$. and then decays to the current temperature distribution at 1.0 m.y., and remains at those values.

Fig. 27 models the histery at $1718 \mathrm{~m}$, the depth of the dated illite, in USW G-1.

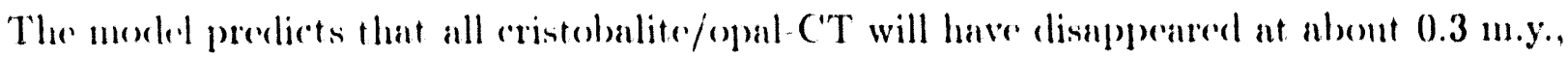
losving approximately $0.1 \mathrm{~m} . \mathrm{y}$. for the regstallization of illite. These predictions agres with the kinetice data of Eberl and Hower (1976) that predict that the smectite/illite transition takes $0.1 \mathrm{~m}, y$. at $75^{\circ} \mathrm{C}$. 'Therefore, the model provides for the arystallization of illite at the correct time. Figs. 28 and 29 show model ralenlations for the present depths

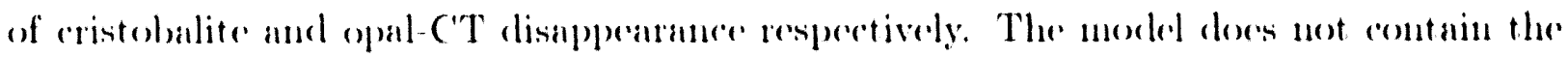
ratre law for the devitritication of glass forming disordered opal-C'T, but assumes that the

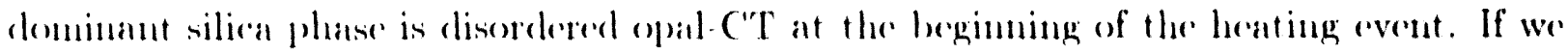

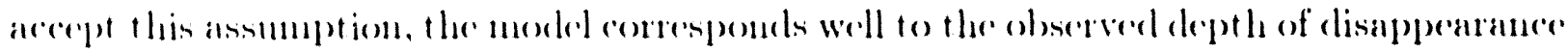
of eristobalite and opal ('T) it prediets $11 \mathrm{~m} . \mathrm{y}$. for the disappearance of opal C'T at $792 \mathrm{~m}$

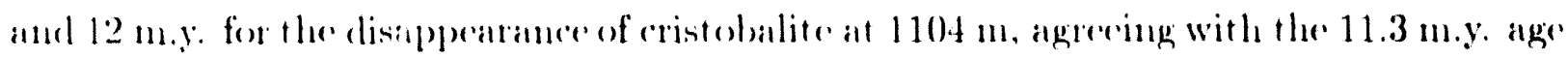
for the onset of Timber Monntain antivity: Similar results are presented in Figs. 30 to 32 for LSW G 2. Althomgh opal C"T has not bern distinguished from cristobalite in USW G-2, its derpest ocemrence has been estimated at $762 \mathrm{~m}$ based on the abrupt increase in quarty rontent. The results for USW G 2 also agree with observation. predicting disalppearance of

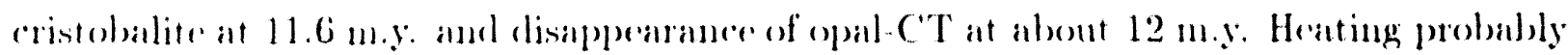
starterl slightly ardieg with emplatement of magna into a shallow chamber (C'hristiansen et al. 1977). If heating was cansed by magma associated with ermption of the Paintbrush Tuff, it may have eommeneed as arly as 13 m.y. B.P. The model results would be similar except that slightly lower maximum temperature wonld be repuired.

I noted callier that higher temperatures have been infered from the observed clay assemblages. Other investigators based this inference primarily on observations in pelitic sediments (Perry and Hower, 1970) Hower, 1981; Bruce, 1984). Figs. 33 to 35 show the results of model calculations for a second temperature history for USW G-2 with a maximmm temperature of $150^{\circ} \mathrm{C}$ at $1181 \mathrm{~m}$. These results are as compatible with the observations as the results with a maximum temporature of $85^{\circ} \mathrm{C}$. However, the interval 


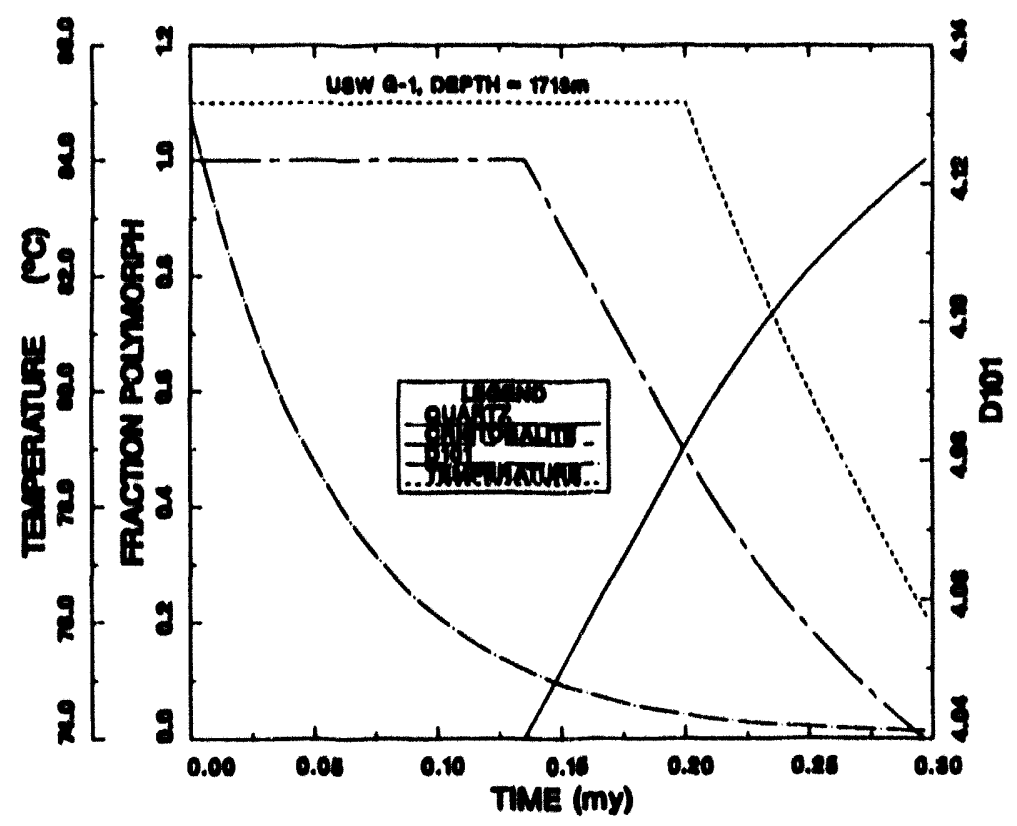

Fig. 27. Model for the evolution of silica polymorphs at $1718 \mathrm{~m}$ in USW G-1, assuming a maximum temperature of $85^{\circ} \mathrm{C}$ was reached at $1718 \mathrm{~m}$.

of maximum tomperature lasted only 2500 years and temperatures returned to current temperatures at 12500 years after the start of the model. The data from pelitic sediments suggest that smectite to illite conversion should require millions of years even at $150^{\circ} \mathrm{C}$. Apparently either the kinetics of smectite-to-illite conversion are consiclerably faster in Yucea Monntain than in pelitic sediments or thermal gradients have been very nonlinear in the past. One possible explanation for faster kinetics of reaction in Yucca Mountain than in pelitic sediments may be a difference in pH. Most of the pelitic sediments which havo been studied are oil shales that, because of a high content of organic acids, may have significantly lower $\mathrm{pH}$ than do Yucca Mountain waters.

If the morlel presented here is correct in that the smectite-to-illite reaction is controlled by $a_{\left.\mathrm{siO})_{2(\mathrm{n}) 1}\right)}$, the rate of conversion of smectite to illite cannot proceed faster than the rate of crystallization of quartz. The rate of quartz crystallization is highly $\mathrm{pH}$ dependent (Duffy, 1993). The distilled water used the by Eberl and Hower (1976) when determining the rate of smectite-to-illite conversion would tend to have produced $\mathrm{pH}$ conditions similar to Yucea Monutain water. The rate determined by Eberl and Hower (1076) is compatible with the rate observed in Yucca Mountain. These observations suggest that pH may influener the rate of smectite-to-illite conversion. 


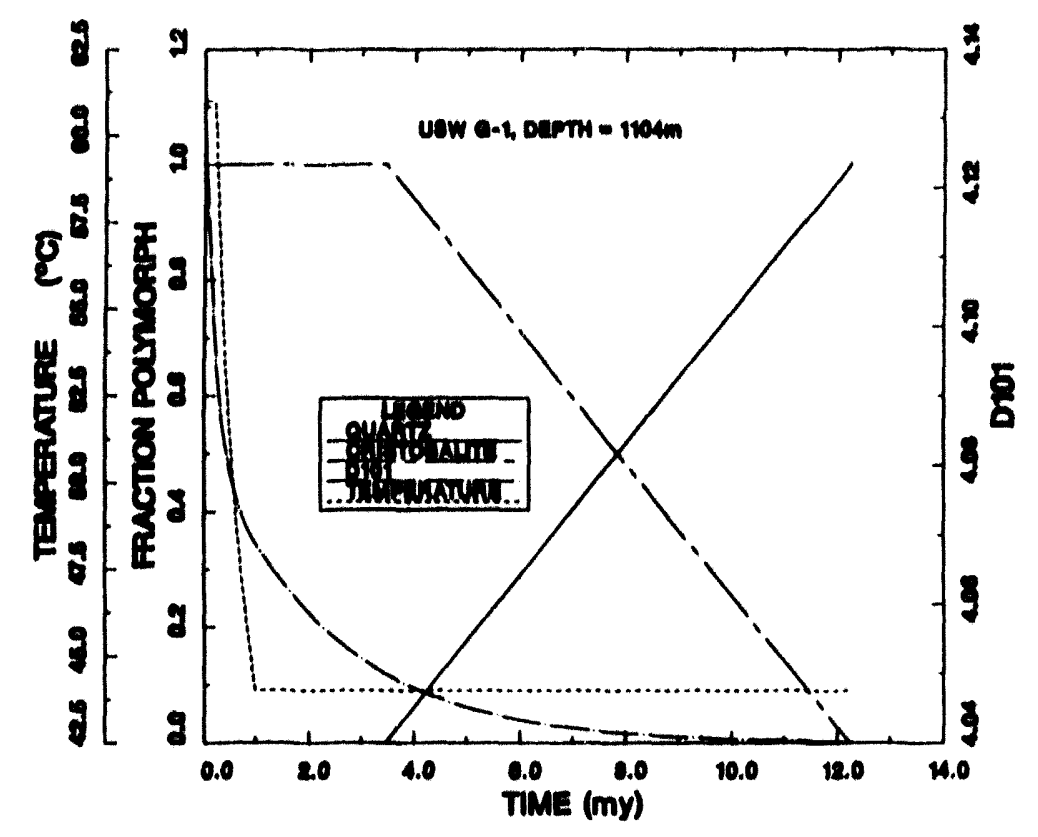

Fig. 28. Model for the cvolution of silien polymorphs at $1104 \mathrm{~m}$ in USW G-1, assmuning a maximum temperature of $85^{\circ} \mathrm{C}$ was reached at $1718 \mathrm{~m}$.

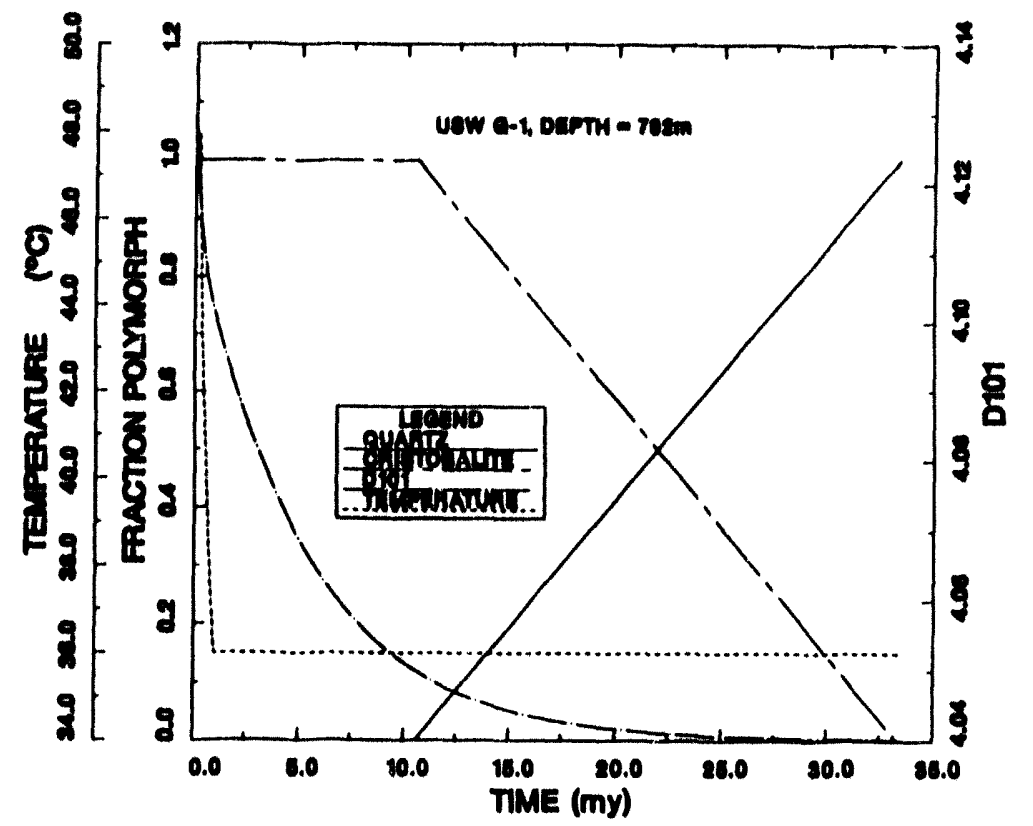

Fig. 29. Model for the evolution of silica polymorphs at $792 \mathrm{~m}$ in USW $\mathrm{G}-1$, assuming a maximum temperature of $85^{\circ} \mathrm{C}$ was reached at $1718 \mathrm{~m}$. 


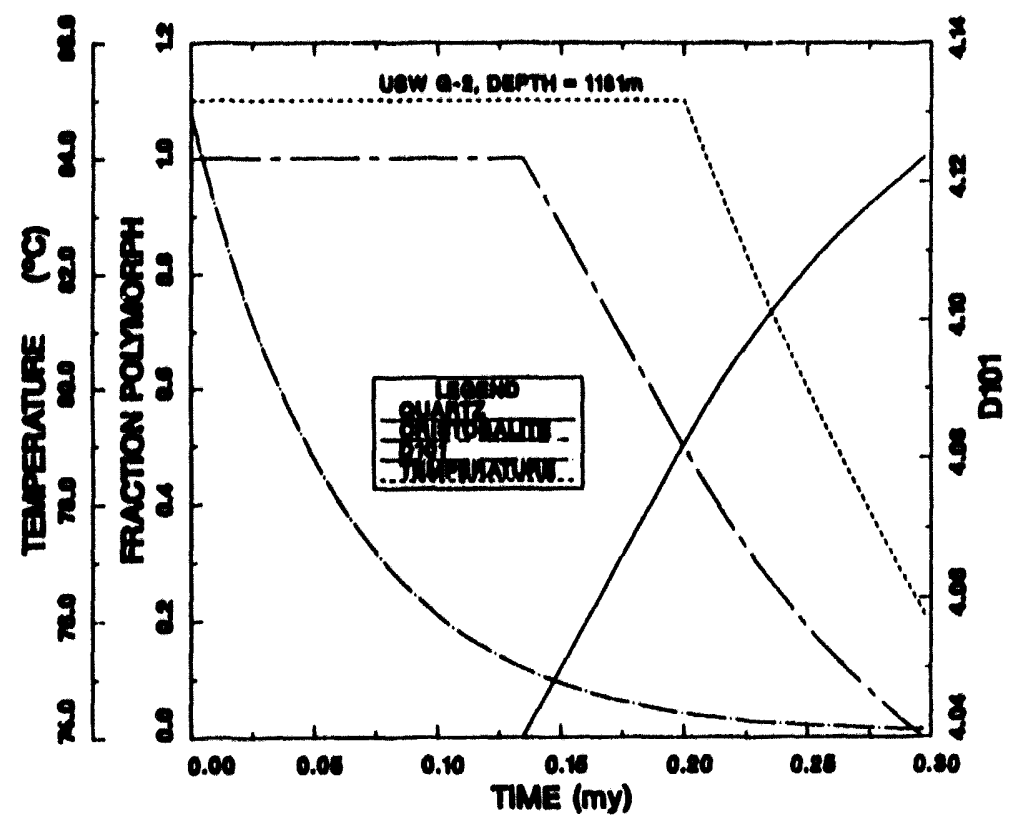

Fig. 30. Model for the evolution of silica polymorphs at $1181 \mathrm{~m}$ in USW G-2, assuming a maximum temperature of $85^{\circ} \mathrm{C}$ was reached at $1181 \mathrm{~m}$.

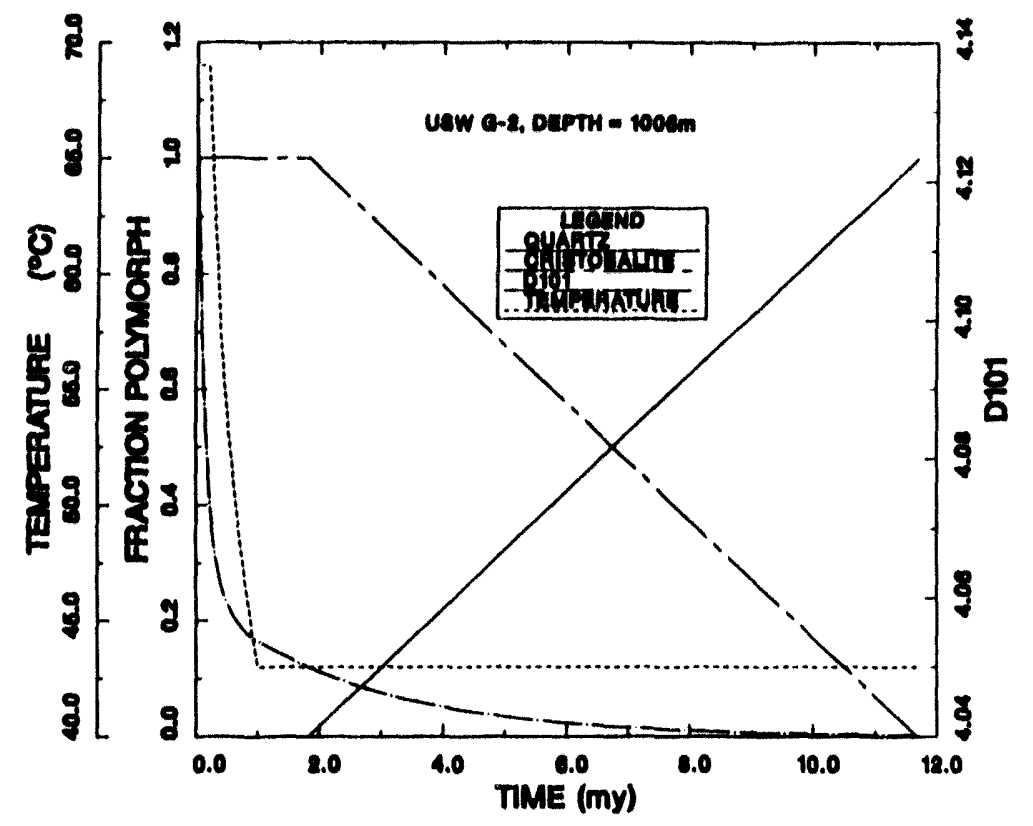

Fig. 31. Morlel for the evolution of silica polymorphs at $1006 \mathrm{~m}$ in USW G-2, assuming a maximum temperature of $85^{\circ} \mathrm{C}$ was reached at $1181 \mathrm{~m}$. 


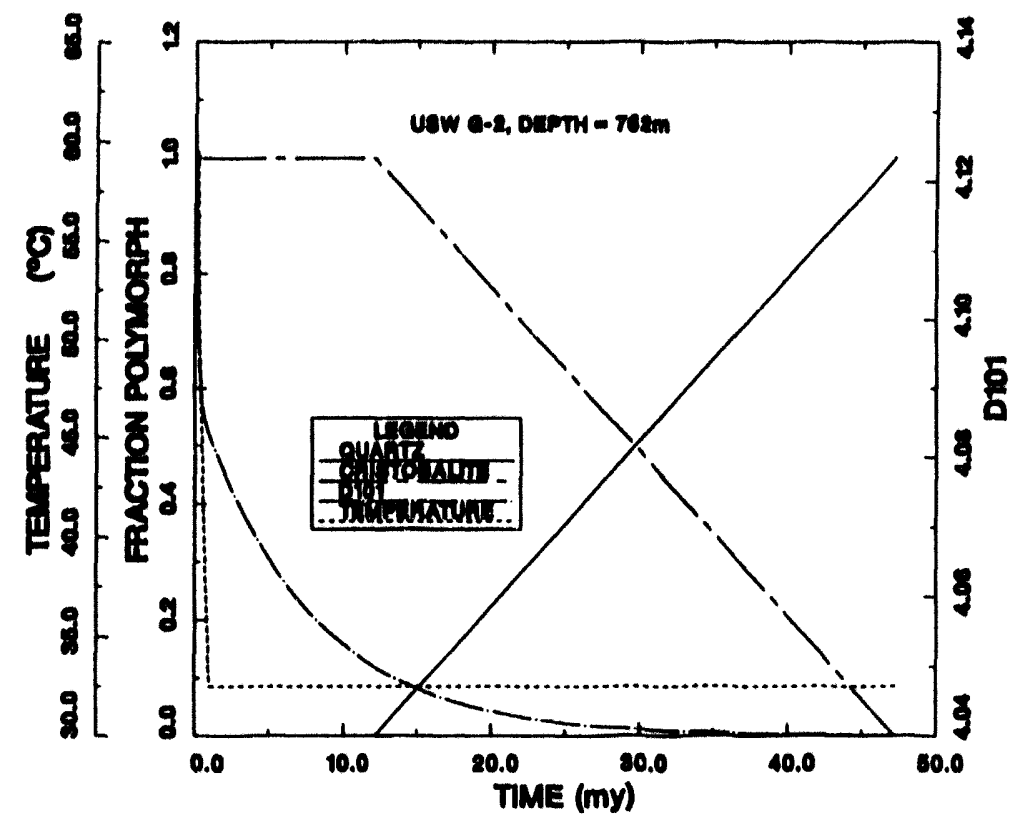

Fig. 32. Model for the evolution of silica polymorphs at $762 \mathrm{~m}$ in USW G-2, assuming a maximum temperature of $85^{\circ} \mathrm{C}$ was reached at $1181 \mathrm{~m}$.

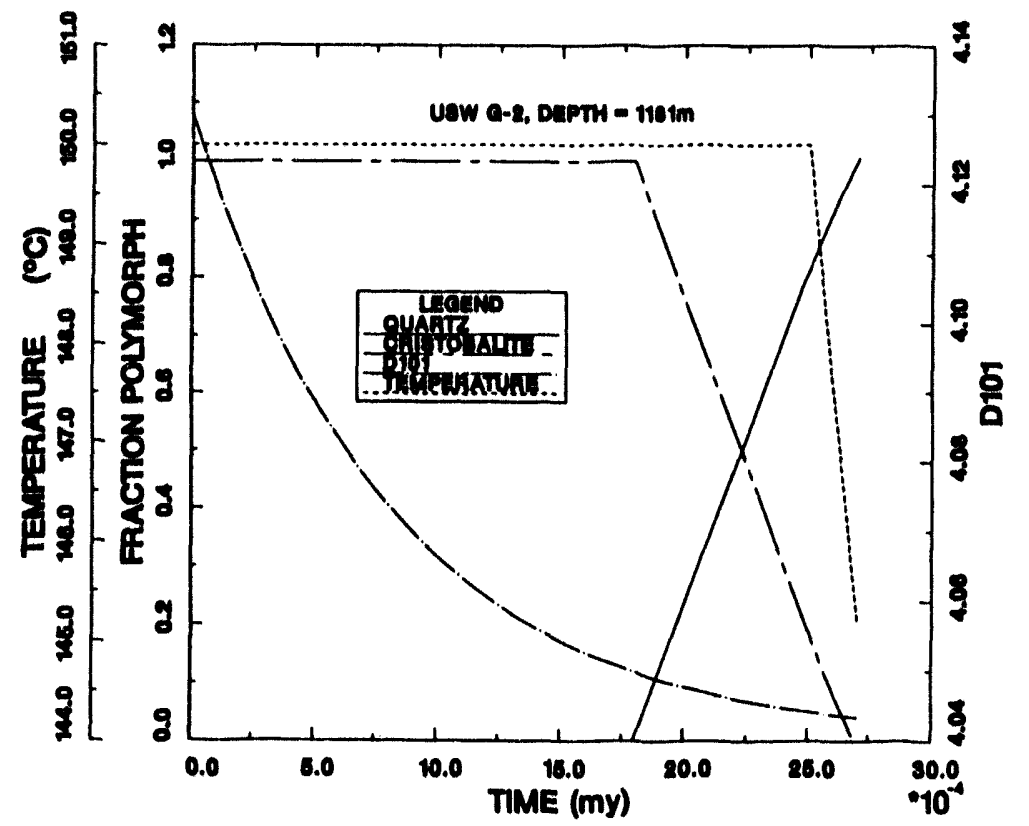

Fig. 33. Model for the evolution of silica polymorphs at $1181 \mathrm{~m}$ in USW G-2, assuming a maxinum temperature of $150^{\circ} \mathrm{C}$ was reached at $1181 \mathrm{~m}$. 


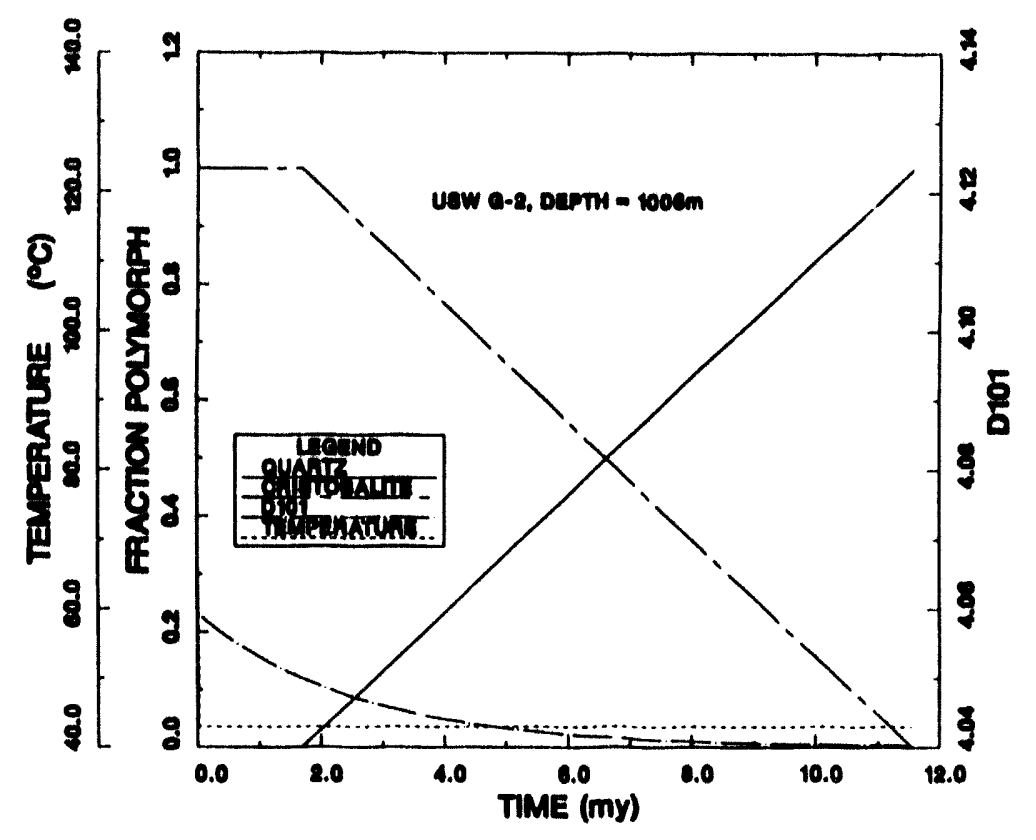

Fig. 34. Model for the evolution of silica polymorphs at $1006 \mathrm{~m}$ in USW G-2, assuming a maximum temperature of $150^{\circ} \mathrm{C}$ was reached at $1181 \mathrm{~m}$.

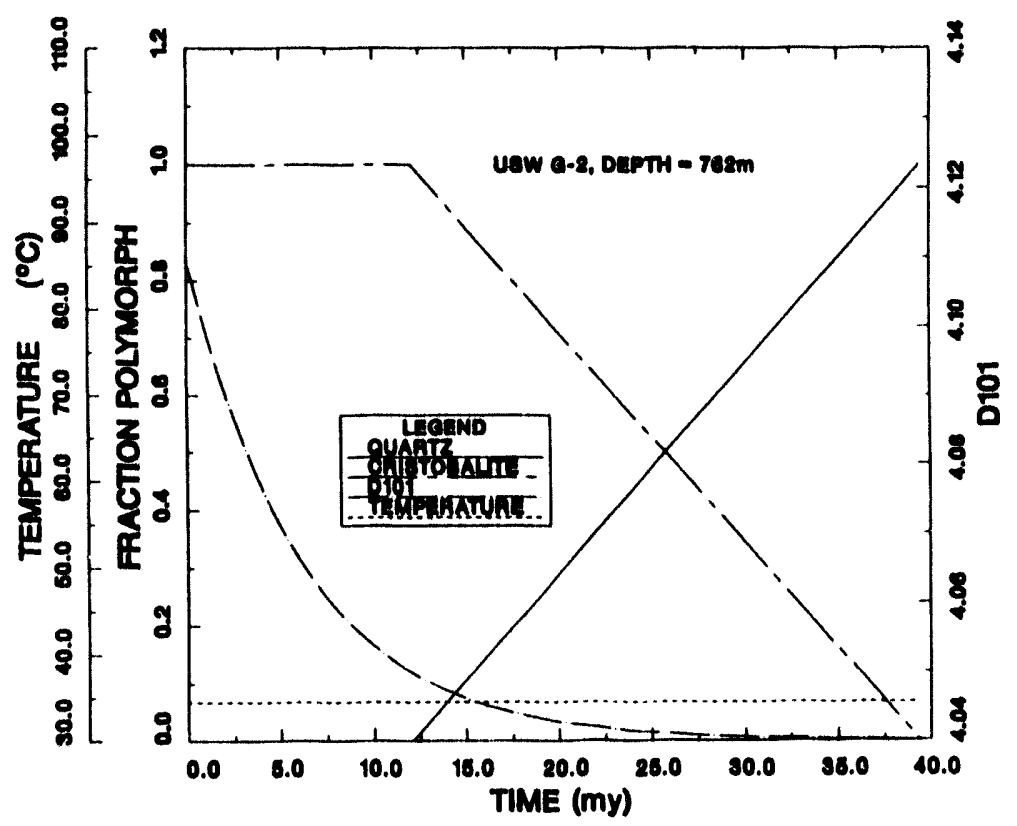

Fig. 35. Model for the evolution of silica polymorphs at $762 \mathrm{~m}$ in USW G-2, assuming a maximum temperature of $150^{\circ} \mathrm{C}$ was reached at $1181 \mathrm{~m}$. 


\section{CONCLUSIONS}

Mineral alteration in Yucca Mountain is primarily controlled by $a_{\mathrm{SiO}_{2(\mathrm{aq})}}$ with $a_{\mathrm{CO}_{3}^{2-}}$ and $\mathrm{pH}$ being of secondary importance. To a first approximation, $a_{\mathrm{SiO}_{2(\mathrm{aq})}}$ appears to be controlled by the solubility of the most soluble silica polymorph present. Because such reactions as the conversion of $\mathrm{K}$-clinoptilolite to $\mathrm{K}$-felclspar can proceed only as $a_{\mathrm{SiO}_{2(\mathrm{aq})}}$ drops, their rates can be constrained by the rate of silica polymorph transformations, if the most soluble silica polymorph controls $a_{\mathrm{SiO}_{2(\mathrm{aq})}}$ at its solubility. If this assumption is made, a simple model for the kinetics of silica polymorph evolution provides a good explanation for the present mineral distribution in Yucca Mountain.

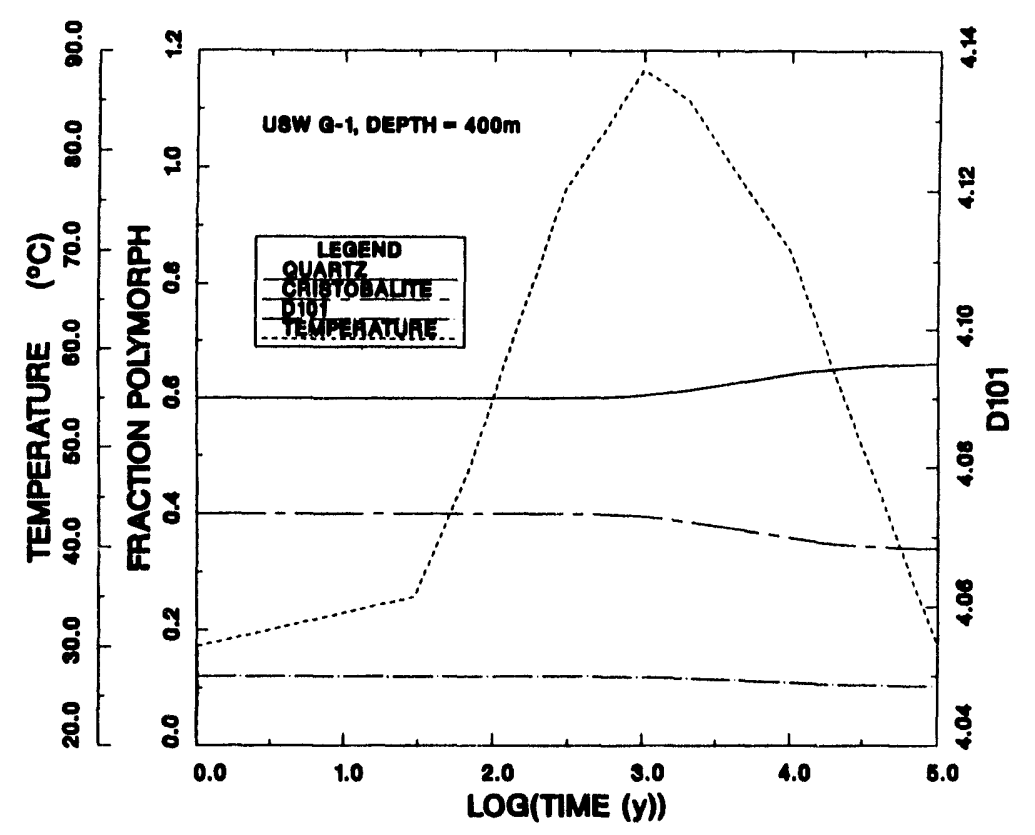

Fig. 36. Predicted future evolution of silica polymorphs at $400 \mathrm{~m}$ in USW G-1.

This kinetic model can be used to predict future mineral alteration. Fig. 36 shows the predicted change in the silica polymorphs at 400-m depth in USW G-1. The calculations shown in this figure use the time/temperature predictions of Johnstone et al. (1984) for limiting properties at the $15 \%$ boundary below the Topopah Spring repository horizon. I assume the opal-CT/cristobalite at this level to be sufficiently ordered for conversion to quartz to proceed at the present time. I assume $60 \%$ of the initial silica polymorph to be quartz with the remaining $40 \%$ cristobalite. The model predicts that there will be an increase on the order of $10 \%$ in the anount of quartz in $100000 \mathrm{yr}$ and that significant 
cristobalite will remain. Therefore, I predict $a_{\mathrm{SiO}_{2(\mathrm{aq})}}$ will remain constant and I expect no mineral alteration except the minor conversion of cristobalite to quartz.

Using the same temperature history as in Fig. 36, Fig. 37 illustrates predicted silica polymorph alteration at $430 \mathrm{~m}$ depth. This location was examined because partially disordered opal-CT is present. Although I expect a small amount of ordering of the opal-CT, the fully ordered state will probably not be reached and no quartz precipitation is expected. The $a_{\mathrm{SiO}_{2(\mathrm{aq})}}$ will decrease slightly; therefore, some K-clinoptilolite will probably convert to K-feldspar and lesser amounts of sodium or calcium clinoptilolite might convert to smectite. Some mordenite will probably also transform to K-feldspar and smectite. Unless the present opal-CT is already highly ordered, which seems unlikely based on the potassium content of the clinoptilolite in the rock, Na-clinoptilolite is unlikely to transform to analcime. Fig. 38 shows predictions for $644-\mathrm{m}$ depth in USW G-1, which corresponds to $85 \%$ boundary below the Topopah Spring repository horizon. I expect minor change in ordering of the opal-CT and quite minor alteration of the type expected at $430 \mathrm{~m}$ at this location.

I base these predictions on the assumption that the kinetics of silica polymorph transformation will not be affected by parameters other than temperature. In particular, if emplacement of a repository caused an increase in the $\mathrm{pH}$ of the surrounding water, the rates of mineral alteration could be greatly accelerated. Increased $a_{\mathrm{CO}_{3}^{2-}}$ could also cause alteration of calcium-rich clinoptilolite and could promote both conversion of clinoptilolite to smectite and smectite to illite. Smectite alteration in the Topopah Spring Member, although possible, has not been examined in detail. At $150^{\circ} \mathrm{C}$, the conversion of the remaining cristobalite to quartz would require only a few hundred years if water is present, which would require fluid pressure of about 5 bar. Once cristobalite disappeared, conversion of smectite to illite would be probable. Such a conversion would probably reduce the sorptive capacity of the rock.

The model suggests that mineral alteration would probably be minor for at least $100000 \mathrm{yr}$ after emplacement of a repository in Yucca Mountain if the thermal model used here is followed; but it also suggests that mineral reactions are occurring in Yucca Mountain at the present time. Some of these reactions involve $\mathrm{H}^{+}$and $\mathrm{CO}_{3}^{2-}$ that must be supplied by the water. Therefore, it may be possible to combine reaction rate clata with water composition clata to help estimate past water fluxes in Yucca Mountain. These studies could be used to examine the flux of water through the basal vitrophyre of the 


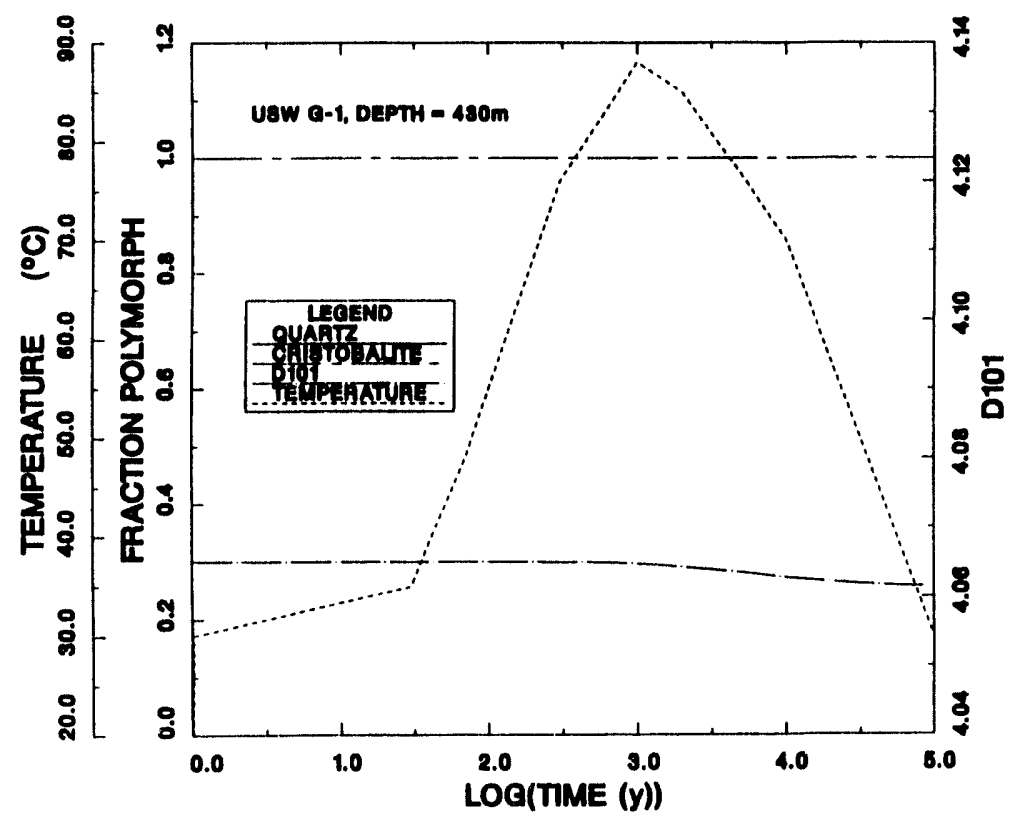

Fig. 37. Predicted future evolution of silica polymorphs at $430 \mathrm{~m}$ in USW G-1.

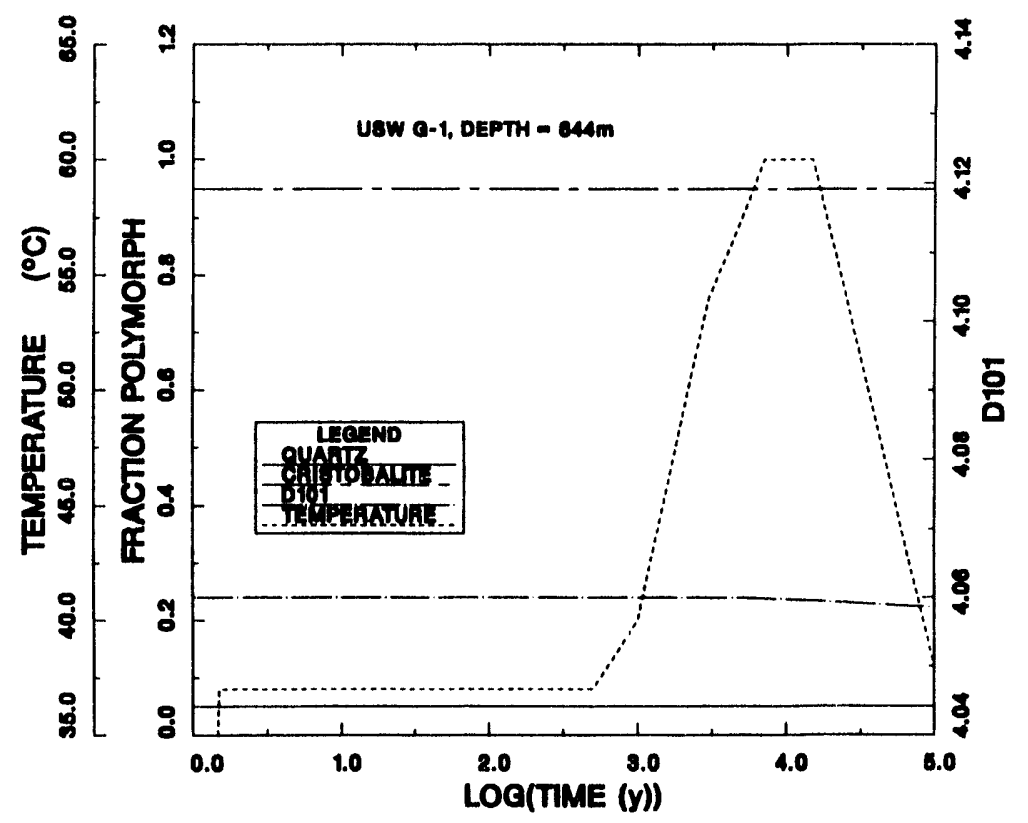

Fig. 38. Predicted future evolution of silica polymorphs at $644 \mathrm{~m}$ in USW G-1. 
Topopah Spring Member and might be linked to variations in $\mathrm{HCO}_{3}^{-}$and $\mathrm{pH}$ across Yucca Mountain to help confirm the direction and rate of flow.

\section{ACKNOWLEDGEMENTS}

I have benefited greatly from discussions with David Bish and David Vaniman. I also owe a great deal to the support and encouragement of Bruce Crowe. This work has been supported by the Nevada Nuclear Waste Storage Investigations Project, which is managed by the Waste Management Project Office of the US Department of Energy.

\section{REFERENCES}

Aagaard, P. and H. C. Helgeson, "Activity/composition relations among silicates and aqueous solutions: II. chemical and thermodynamic consequences of ideal mixing of atoms on homological sites in montmorillonites, illites, and mixed-layer clays," Clays and Clay Minerals 31, 207-217 (1983). NNA.891006.0210

Bish, D. L. and R. Ellen Semarge, "Mineralogic variations in a silicic tuff secuence: Eviclence for diagenetic and hydrothermal reactions," Nineteenth Circum-Pacific Clay Minerals Society Annual Meeting, Hilo, Hawaii, 1982. NNA.870406.0234

Bish, D. L. and S. J. Chipera, "Mineralogy of drill holes J-13, UE-25A\#1, and USW G-1 at Yucea Mountain, Nevada," Los Alamos National Laboratory report LA-10764-MS (September 1986). NNA.890523.0057

Bish, D. L. and D. T. Vaniman, "Mineralogic summary of Yucca Mountain, Nevarla," Los Alamos National Laboratory report. LA-10543-MS (October 1985). NNA.870407.0330)

Broxton, D. E., D. L. Bish, and R. G. Warren, "Distribution and chemistry of diagenetic minerals at Yucca Mountain, Nye Comnty, Nevada," Clays and Clay Minerals 35, 89-110 (1987). NNA.890222.0053

Broxton, D., D. Vaniman, F. Caporuscio, B. Arney, and G. Heiken, "Detailed petrographice descriptions and microprobe data for drill holes USW-G2 and UE25b-1h, Yucca Monutain, Nevarla," Los Alamos National Laboratory report LA-9324-MS (October 1982). NNA.931029.0052

Broxton, D. E., R. G. Warren, R. C. Hagan, and G. Luedemann, "Chemistry of cliagenetically altered tuffs at a potential nuclear waste repository, Yucea Momntain, Nye 
County, Nevarla," Los Alamos National Laboratory report LA-10802-MS (O)tober 1986). NNA.890327.0036

Bruce, C. H., "Snectite dehydration Its relation to structural development and hycleocarbon accumulation in northern Gulf of Mexico Basin," A.APG Bull. 68, 673-683 (1984). NNA.900508.0011

Caporuscio, F., D. Vaniman, D. Bish, D. Broxton, B. Arney, G. Heiken, F. Byers, R. Gooley, and E. Semarge, "Petrologic studies of drill cores USW-G2 and UE251)1H, Yucca Mountain. Nevada," Los Alamos National Laboratory report LA -9255-MS (July 1982). NNA.870519.0041

Carlos, B. A., "Minerals in fractures of the unsaturated zone from drill core USW G4, Yuca Monutain, Nye Connty, Nevarla," Los Alamos National Laboratory report LA-10415-MS (April 1985). NNA.920506.0037

Carlos, B. A., "Minerals in fractures of the satumated zone from rlrill core USW G-4, Yucra Momntain, Nye Connty, Nevala." Los Alamos National Labomatory report LA-1092TMS (April 1987). NNA.870708.0026

Christiansen, R. L.. P. W. Lipman. W. J. Carr, F. M. Byers Jr., P. P. Orkild, and K. A. Sargent, "Timber Monntain-()asis Valley ablelea complex of southern Nevalal." Geological Society of America Bulletin 88. 943-959 (1977). NNA.870406.0166

Deer, W. A., R. A. Howie, and .J. Zussman, Rock-Forming Mineruls. 3. Sheet Silicates, Longmans, Green and C'o. Ltd., London (1962), pp. 164-212. NNA.931029.()()43

Dibble W. E., Jr., and W. A. Tiller, " Kinetic model of zeolite paragenesis in tuffaceons sediments," Clays and Clay Minerals 29, 323-330 (1981). NNA.870406.0093

Duffy, C. J., "Letter report on the thermodynamies of analcime," TWS-INC7-4/85-10 Los Alamos National Laboratory momorandum, (1985). NNA.900709.0172

Duffy, C'. J.. "Kinetics of silica phatse transitions," Los Alamos National Laboratery report LA-12564-MS (July 1993). NNA.900112.0346

Eberl, D. and J. Hower, "Kinetics of illite formation," Geological Society of Anerica Bulletin 87, 1326-1330 (1976). NNA.931029.0045 
Ernst W. G. and S. E. Calvert, "An experimental study of the recrystallization of porcelanite and its bearing on the origin of some bededed cherts," American Journal of Science 267-A, 114-133 (1969). NNA.900508.0013

Garrels, R. M., "Montmorillonite/illite stability diagrams," Clays and Clay Minerals 32 , 161-166 (1984). NNA.900508.0014

Honda, S. and L. J. P. Muffler, "Hydrothermal alteration in core from resenrch drill hole Y-1, Upper Geyser Basin, Yellowstone National Park, Wyoming," American Mineralogist 55, 1714-1737 (1970). NNA.931029.0045

Hower, J., "Shale diagenesis," Short course in clays and the resource geologist, F. J. Longstgffe, Ed., (Mineralogical Association of Canada, Calgary, 1981), pp. 60-80. NNA.931029.0046

Johnstone, J. K., R. R. Peters, and P. F. Ginirk, "Unit evaluation at Yucca Monutain, Nevada Test Site: Summary report and recommendations," Sandia National Laboratories report SAND83-0372 (June 1984). NNA.870519.0052

Kano, K., "Ordering of opal-CT in cliagenesis," Geochemical Journal 17, 87-93 (1983). NNA.930420.0069

Keith, T. E. C., D. E. White, and M. H. Beeson, "Hydrothermal alteration and self sealing in $Y-T$ and $Y-8$ drill holes in northern part of Upper Geyser Basin, Yellowstone National Park, Wyoming," US Geological Survey Professional Paper 1054-A (1978). NNA.931029.0051

Kerrisk, J. F., "Reaction-path calculations of groundwater chemistry and nineral formation at Rainier Mesa, Nevada," Los Alamos National Lalomatory report LA-9912-MS (Derember 1983). NNA.870310.0007

Kerrisk, J. F., "Groundwater chemistry at Yucea Mountain, Nevala, and vicinity," Los Alamos National Laboratory report LA-10920-MS (Fobruary 1987). NNA.870507.0017

Levy, S. S., "Petrology of samples from drill holes USW H-3, H-4, and H-5, Yucra Momutain, Nevala," Los Alamos National Laboratory report LA-9706-MS (June 1984). NNA.870519.0048

Marvin, R. F., F. M. Byers, Jr., H. H. Mehnert, P. P. Orkild, and T. W. Stern, " Racliometric ages and stratigraphice serfuenee of volcanic and plutonie rocks, sonthern Nye 
and western Lincoln Comnties, Nevuda," Geological Society of America Bulletin 81, 2657-2676(1970). NNA.870406.0301

Moiola, R. J., "Anthigenic zeolites and Kefolelspar in the Esmeralda Formation, Nevada," Anerican Mineralogist 55, 1681-1691 (1970). NNA.931029.0050)

Murata, K. J. and R. R. Larsou, "Diagenesis of miocene siliceons shales, Temblor Range, California," Jour. Research. U.S. Geol. Survey 3, 553-566 (1975). NNA.930420.0075

Perry, E. and J. Hower, "Burial diagenesis of gulf' coast pelitic serliments," Clays and Clay Mincrals 18, 165-17T(1970). NNA.900508.0026

Perry, E. A.. Jr. and J. Hower, "Late stage deleydration in deeply buried pelitie sediments," AAPG Bull. 56, 2013-2021 (1972). NNA.931029.0049

Roberson, H. E. and R. W. Lahamn. "Snertite to illite conversion rates: Effects of solution rhemistry," Clays and Clay Minerals 29, 129-135 (1981). NNA.931029.0048

Sass, J. H., and A. H. Lachenbruch. "Preliminary interpretation of thermal data from the Serarla Test Site." LS Geological Survey (Open File Report 82-973 (1982). NNA.8T(0406.0040

Sass, J., A. Lachenbruch. F. Grubl, and T. Moses, "Status of thermal observations at Vucca Momutain. Nevada," US Geological Survey Letter Report (April 1983). NNA.931029.0047

Suyth. J. R., " Zeolite stability enstraints on rarlionctive waste isolation in zeolite-bearing volranic rocks." Jommal of Gieology 90, 195-201 (1982). NNA.87(0406.0187

Vaniman, D.. D. Bish, D. Broxton, F. Byers, G. Heiken, B. Carlos, E. Semarge, F. Caporuscio, and R. Gooley, "Variations in authigenie mineralogy aud sorptive zeolite abundance at Yucra Momutain. Nevada, baserl on studies of drill cores USW GU-3 and G-3," Los Alamos National Laboratory report LA-9707-MS (June 1984). NNA.870519.0043

Walther, J. V. and H. C'. Helgeson, "Calculations of the thermorlynamie properties of atpueous silica and the solubility of quart\% and its polymorphs at high pressures and temperatures." Anerican Journal of Seience 277, 1315-1351 (1977). NNA.921124.(0013 
Zen, E., "Problem of the thermodynamic status of the mixed-layer minerals," Geochinica et Cosmochimica Acta 26, 1055-1067 (1962). NNA.9005(1)8.0032 


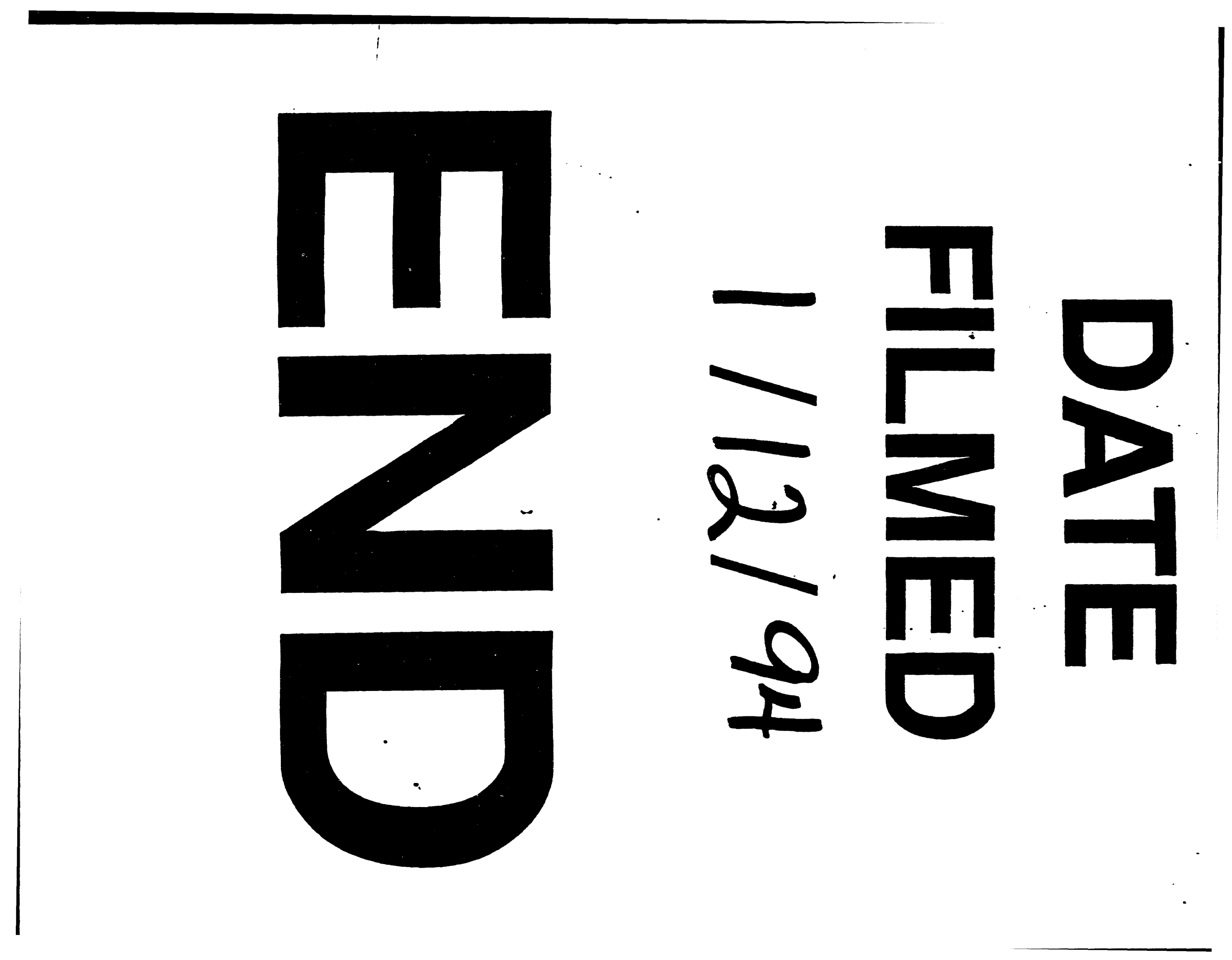


$$
\text { - }
$$ 